\title{
Central Europe, 1531-1540 CE: The driest summer decade of the past five centuries?
}

\author{
Rudolf Brázdil $^{1,2}$, Petr Dobrovolný ${ }^{1,2}$, Martin Bauch $^{3}$, Chantal Camenisch ${ }^{4,5}$, Andrea Kiss ${ }^{6,7}$, Oldřich Kotyza ${ }^{8}$, \\ Piotr Oliński ${ }^{9}$, and Ladislava Řezníčková ${ }^{1,2}$ \\ ${ }^{1}$ Institute of Geography, Masaryk University, Brno, Czech Republic \\ ${ }^{2}$ Global Change Research Institute, Czech Academy of Sciences, Brno, Czech Republic \\ ${ }^{3}$ Leibniz Institute for the History and Culture of Eastern Europe (GWZO), Leipzig, Germany \\ ${ }^{4}$ Oeschger Centre for Climate Change Research, University of Bern, Bern, Switzerland \\ ${ }^{5}$ Institute of History, University of Bern, Bern, Switzerland \\ ${ }^{6}$ Institute for Hydraulic Engineering and Water Resources Management, Vienna University of Technology, Vienna, Austria \\ ${ }^{7}$ Department of Historical Auxiliary Sciences, Institute of History, University of Szeged, Szeged, Hungary \\ ${ }^{8}$ Regional Museum, Litoměřice, Czech Republic \\ ${ }^{9}$ Institute of History and Archival Sciences, Climate Change Research Unit, University of Toruń, Toruń, Poland
}

Correspondence: Rudolf Brázdil (brazdil@sci.muni.cz)

Received: 9 July 2020 - Discussion started: 20 July 2020

Revised: 21 September 2020 - Accepted: 30 September 2020 - Published: 9 November 2020

\begin{abstract}
Based on three drought indices (SPI, SPEI, Zindex) reconstructed from documentary evidence and instrumental records, the summers of 1531-1540 were identified as the driest summer decade during the 1501-2015 period in the Czech Lands. Based on documentary data, extended from the Czech scale to central Europe, dry patterns of various intensities (represented, for example, by dry spells, low numbers of precipitation days, very low rivers, and dryingout of water sources) occurred in 1532, 1534-1536, 1538, and particularly 1540 , broken by wetter or normal patterns in 1531, 1533, 1537, and 1539. Information relevant to summer droughts extracted from documentary data in central Europe was confirmed in summer precipitation totals from a multiproxy reconstruction for Europe by Pauling et al. (2006) and further by self-calibrated summer Palmer Drought Severity Index (PDSI) reconstruction from tree ring widths in Old World Drought Atlas (OWDA) by Cook et al. (2015). The summer patterns described are consistent with the distribution of sea level pressure deviations from a modern reference period. Summer droughts were responsible for numerous negative impacts, such as bad harvests of certain crops, reduction and lack of water sources, and frequent forest fires, while in the wetter summers central Europe was affected by floods. However, there are no indications of severe impacts of
\end{abstract}

a multi-country or multi-year effect. Reconstructions based on documentary data indicate that the summers of 15311540 constitute the driest summer decade in central Europe for the past five centuries between 1501 and $2010 \mathrm{CE}$.

\section{Introduction}

Information related to droughts and their impacts derived from documentary evidence (Brázdil et al., 2018, 2019c) may be used for detailed analyses of individual severe drought events in the past (e.g. Munzar, 2004; Wetter et al., 2014; Kiss and Nikolić, 2015; Roggenkamp and Herget, 2015; Brázdil et al., 2016b, 2019a; Kiss, 2017, 2020; Bauch et al., 2020; Camenisch et al., 2020) and for creation of a range of long-term drought chronologies (e.g. MartínVide and Barriendos Vallvé, 1995; Piervitali and Colacino, 2001; Domínguez-Castro et al., 2008; Diodato and Bellocchi, 2011; Brázdil et al., 2013a; Garnier, 2019; Tejedor et al., 2019; Przybylak et al., 2020). It is even possible, by means of documentary-based temperature and precipitation reconstructions, to calculate long-term series of drought indices overlapping the pre-instrumental and instrumental periods (Brázdil et al., 2016a). Drought indices may also be recon- 
structed from drought-sensitive phenological series, such as those for grape harvest dates (Možný et al., 2016). Reported series of drought indices further allow comparison of the severity of drought episodes over several centuries (Brázdil et al., 2019b), as well as analysis of the effects of external forcings and large-scale climate variability modes upon droughts (Mikšovský et al., 2019).

Papers presenting overviews, both worldwide and European, of documentary-based drought studies have been published in recent years (Brázdil et al., 2018, 2019c). In Europe, the warm and dry weather of the year 1540 has attracted considerable attention. Wetter and Pfister (2013) considered 1540 as exceptionally hot for Europe, comparable with the outstanding summer event of 2003, when between 22000 and 35000 heat-related deaths were recorded across modern Europe (e.g. Schär and Jendritzky, 2004; Chase et al., 2006; Fischer et al., 2007). Subsequently, Wetter et al. (2014) presented 1540 as extremely dry on the broader European scale, coining the term "megadrought" for an unprecedented drought extending for 11 months. This paper and the term "megadrought" gave rise to controversy. Büntgen et al. (2015) questioned its results on dendroclimatological grounds, then Pfister et al. (2015) responded, pointing out the complexity of the whole drought phenomenon, as did the authors of the first 1540 drought paper. Subsequently, Orth et al. (2016) investigated whether European temperatures in 1540 are comparable with present-day (1966-2015) mean summer temperatures, while certain other authors using documentary data returned to the weather patterns of 1540 (Kiss, 2018; Pfister, 2018; Nowosad and Oliński, 2020).

However extremely dry 1540 proved to be, other summer drought episodes also occurred in the decade of 15311540 , some of them close to one another, resulting in a notably high frequency of dry episodes in this decade within the long-term drought chronology of the Czech Lands dating back to 1501 CE (Brázdil et al., 2013a). Indeed, it may well have been the driest decade in half a millennium of reconstructed series of three summer drought indices (Brázdil et al., 2016a). Further, indications of dry summers during the 1531-1540 decade also follow from documentary data and related documentary-based hydroclimatic patterns of some other central European countries, such as Germany (Glaser, 2008) and Poland (Limanówka, 2001).

This study aims to utilize and analyse documentary evidence from central Europe systematically to investigate the hypothesis that the summers of the decade 1531-1540 could have been the driest in over the past 500 years. Section 2 presents the documentary data used together with European precipitation, PDSI, sea level pressure, and temperature reconstructions. After descriptions of methods in Sect. 3, documentary data for the individual summers of 1531-1540 are reported, and then related to spatial expression of precipitation totals and PDSI in Sect. 4, further complemented by circulation patterns of the summers investigated, long-term fluctuations of a number of climatological variables, impacts upon the life of the population, and people's responses to such summer weather. The discussion in Sect. 5 concentrates on the broader context of the results obtained, as well as impacts and human responses. The last section summarizes the results of the paper into few concluding remarks.

\section{Data}

\subsection{Documentary data}

Documentary evidence consists of a broad range of sources containing information about the weather, related phenomena, socio-economic consequences, and human responses to them (Brázdil et al., 2005, 2010; White et al., 2018). The main types of documentary sources related to hydroclimatic patterns appear below, with examples from the summers of 1531-1540. Because many of the actual sources were dated according to the Julian calendar, $10 \mathrm{~d}$ have been added where appropriate to express them in the more recent Gregorian calendar (Friedrich, 1997).

\section{i. Narrative sources.}

Different types of narrative sources contain descriptions of weather patterns and their impacts, including annals, chronicles, "books of memory", and private diaries. Large numbers of sources have already been professionally worked up and published as critical editions, but some still remain in archival collections in handwritten form. An example of subsequently published annals may be found in the records of Nikolaus Pol, a town scribe in Silesian Wrocław (see Fig. S1 in the Supplement), who wrote of summer 1532 (Büsching, 1819, p. 72):

Dry summer. It did not rain for seven weeks. Cereals and pastures withered totally. There was no water in several settlements. In the countryside, it was impossible to grind [grain]. People had to go 10, 12, 18 miles [converting the Breslau mile, ca. 66, 79 and $119 \mathrm{~km}$ ] to [get to] mills. The River Oława dried up and had no water until St. Bartholomew's Day [3 September].

Councillor scribes from Litoměrice in Bohemia reported patterns of the 1538 summer in their chronicle (Smetana, 1978, p. 133):

It was very dry, [people] walked and rode [by cart] over the Elbe. The vintage started before Saint Jiljí [11 September] and exactly at [the feast of] Saints Peter and Paul [9 July] the grapes became soft; there had been no year like it for seventy years. 


\section{ii. Weather diaries.}

More-or-less systematic daily records kept in weather diaries enable calculation of the frequency of certain characteristics (e.g. number of precipitation days) and the use of any related additional notes. In Polish Kraków, astronomers systematically entered qualitative daily weather records into their specialist calendars ("ephemerides"). Marcin Biem of Olkusz (ca. 14701540), astronomer, theologian, and professor and rector of the Kraków Academy, kept daily records for 15311540, although from 1532 to 1534 they are incomplete or missing (Limanówka, 2001). For example, after some quite hot and nice days between 28 July and 2 August 1537 , he described the weather in the first $10 \mathrm{~d}$ of August (ibid., p. 30):

3. Weather nice and hot, strong wind, rain in the night. 4. Cloudy in the morning, nice weather from noon, terrible thunderstorm with lightning in the evening. 5. Changeable weather, rain showers, lightning and wind. 6.8. Rain every day. 9. Clear with light wind, more sunshine than rain. 10. Continuous rain and very strong wind.

A somewhat unusual source consists of the daily military diaries of Turkish Emperor Suleiman, who described basic weather conditions from the central region of the Ottoman Empire, through the Balkan Peninsula to the Carpathian Basin and Lower Austria. For example, for the rainy end of June and beginning of July 1532 he made the following notes (Thúry, 1893, p. 350):

Year 938 [1532]. month [of] Zil-kade / [...] / 17 [25 June]. Friday. Stationed at Al-Kilise. Much rain fell. / 18 [26 June]. Saturday. Same place. It was raining. / 19 [27 June]. Sunday. Stationed at Elie [Ralie?]. Much rain fell. / 20 [28 June]. Monday. Stationed at Hisarlik. A great deal of rain [fell]. / 21 [29 June]. Tuesday. Arrived in Belgrade. A great deal of rain [fell]. / 22 [30 June]. Wednesday. Staying in place so that the army could cross the bridge. / 23 [1 July]. Thursday. The Padishah built a bridge [opposite] to Belgrade, [we] crossed the Sava bridge and settled in the Serim Plain. The Pasha came to meet him with an army of Rumelians. A great wind blew and it rained. / 24 [2 July]. Friday. Stayed in place. It rained. The Anatolian army crossed the bridge and stayed in Serim. / 25 [3 July]. Saturday. Stayed in place. It rained. / 26 [4 July]. Sunday. Stayed in place. It rained. / 27 [5 July]. Monday. Stayed in place. It rained. iii. Account books.

Books of accounts may contain records of municipal payments made for work related to weather and/or its extremes. In the town of Louny (north-western Bohemia), wages for municipal work in the previous week were paid regularly on a Saturday (Brázdil and Kotyza, 2000), providing indirect information about weather impacts. For example, records of harvest works may indicate wetter patterns (interruption of harvest, late beginning and end of harvest) or drier ones (earlier and shorter harvest times). For example, the course of field labour in 1531 was evidently impaired by downpours in the week before 25 July when "hay was pulled out of the water and dried" and the harvesters were paid wages "for three days, for half a day, not for the whole week" (archival source AS14, fol. 148v). Other detailed account books helpful to the current study originate from Vienna (Austria) and Bratislava (Slovakia), where expenses related to grain- and vineharvesting work or compensation for damage arising out of weather-related extremes, together with suggestions concerning the cause (and magnitude) of destruction, were recorded. Kiss (2018) analysed the grape and grain harvest dates from Vienna hospital accounts with respect to the extreme year of 1540. An example from the Bratislava accounts reports a late grape harvest, on 26 October 1533:

On the day of Luca [16 October] the Chamberlain was asked to have the harvesting of the vineyards announced [...] (AS1, K83/135, 176).

\section{iv. Chronograms.}

Chronograms commemorate significant events or years in which people have been heavily affected. Selected letters (in capital letters or in bold type) are interpreted as Roman numbers indicating the year of an event. An example may be found in a commemoration of the 1540 drought in certain German sources (Riedel, 1862, p. 104):

"EXICCata LeVIs CVr fLVMIna CerVi reqVIrIs" ["Why do you seek the swift deer when the rivers have gone dry?"], thus

$\mathrm{X}+\mathrm{I}+\mathrm{C}+\mathrm{C}+\mathrm{L}+\mathrm{V}+\mathrm{I}+\mathrm{C}+\mathrm{V}+\mathrm{L}+\mathrm{V}+\mathrm{M}+\mathrm{I}$

$+\mathrm{C}+\mathrm{V}+\mathrm{V}+\mathrm{I}+\mathrm{I}=10+1+100+100+50+5$

$+1+100+5+50+5+1000+1+100+5+5+1$

$+1=1540$ ).

The same sentence also appeared in handwritten remarks made concerning 1540 on calendars in southern Transylvania (Schuller, 1848, p. 356). 


\section{v. Non-contemporaneous sources.}

There exist considerable quantities of handwritten or printed materials describing a past event not directly experienced but based on then-existing or lost documentary evidence, which may be characterized as documentary sources. However, they require a degree of critical work to establish their reliability and potential for complementing information derived from primary sources. An example may be found in a work by one Daniel Gomolcke, printed in 1737, which includes accounts, usually short, of weather conditions together with longer descriptions of the economic consequences for Silesian society, with additional remarks. For example, for summer 1534 he made the following note (Gomolcke, 1737, pp. 10-11):

There was a great drought over Silesia in 1534, and a hot summer from Easter [15 April] to St. Bartholomew's day [3 September]. Water dried out, [to the extent] that watermills were out of operation, everything had to be ground by "Rossmühlen" [mills powered by horses]; high prices followed [...].

The Chronicle of Gaspar Hain from Levoča in Slovakia (Bal et al., 1910-1913), originating from the second half of the 17th century, is particularly reliable for the 16th century, since the author used official documentation from the local town archives and also provided precise names of the town mayors or notaries from whose notes he derived his information.

\section{vi. Weather compilations.}

Weather compilations may contain information concerning various weather patterns and phenomena. However, they are often eclectic, gathered from a wide range of evidence that differentiates neither between primary and secondary accounts nor contemporaneous and non-contemporaneous sources. For example, weather data for 1531-1540 appear in several compilations related to central European countries such as Poland (Walawender, 1932; Rojecki et al., 1965) and regions that belonged to historical Hungary (Réthly, 1962), but use of their data entails a critical evaluation against other existing reports. Some collections of historical-climatological data have been incorporated into generally accessible electronic databases, such as the Swiss EuroClimhist (Pfister and Rohr, 2015) and the German CLIMDAT (Militzer, 1998) and Tambora (Riemann et al., 2015).

\subsection{Hydroclimatic, pressure, and temperature reconstructions}

Three types of hydroclimatic reconstructions were used to document spatio-temporal variability of summer (JJA) precipitation and droughts in central Europe.

i. Seasonal series of three drought indices were calculated for what is now the Czech Republic in the 1501-2015 period (Brázdil et al., 2016a): Standardised Precipitation Index (SPI; McKee et al., 1993), Standardised Precipitation Evapotranspiration Index (SPEI; Vicente-Serrano et al., 2010), and Z-index (Palmer, 1965). Reconstructed central European temperature series (Dobrovolný et al., 2010) and Czech precipitation series (Dobrovolný et al., 2015), derived from series of documentary-based temperature-precipitation indices and instrumental measurements, provided the target data for these calculations.

ii. Long series of instrumental precipitation measurements, documentary-based precipitation indices, and natural proxies sensitive to precipitation signals (tree rings, ice cores, corals, and speleothems) were employed by Pauling et al. (2006) to calculate seasonal precipitation totals throughout Europe for the 1500-2000 period. Their reconstruction combines gridded values $\left(0.5^{\circ}\right.$ latitude $\times 0.5^{\circ}$ longitude $)$ for the European land mass $\left(30-71^{\circ} \mathrm{N}, 30^{\circ} \mathrm{W}-40^{\circ} \mathrm{E}\right)$ in the years from 1500 to 1900 with a gridded reanalysis for the years 19012000 by Mitchell and Jones (2005). The data are available at https://www.ncdc.noaa.gov/paleo-search/study/ 6342 (last access: 8 January 2020).

iii. Tree ring widths were used to calculate the gridded $\left(0.5^{\circ} \times 0.5^{\circ}\right)$ summer self-calibrated Palmer Drought Severity Index (scPDSI) for The Old World Drought Atlas (OWDA) (Cook et al., 2015), covering the 02012 CE period (http://drought.memphis.edu/OWDA/ Default.aspx, last access: 8 January 2020).

iv. Circulation patterns for the summers of 1531-1540 in central Europe may be addressed via maps of the European mean sea level pressure (SLP) field over the Atlantic-European sector based on $5^{\circ}$ longitude $\times 5^{\circ}$ latitude grids, as reconstructed by Luterbacher et al. (2002b). Their data are available at https: //www.ncdc.noaa.gov/paleo-search/study/6366 (last access: 22 May 2020).

v. Gridded European summer temperature data from the reconstruction by Luterbacher et al. (2004) are similarly available at https://www.ncdc.noaa.gov/paleo-search/ study/6288 (last access: 22 May 2020). 


\section{Methods}

With the territorial focus on central Europe, represented particularly by Germany, Switzerland, Austria, the Czech Republic, Poland, Slovakia, Hungary, and Transylvania (western Romania), available documentary data from the various sources described in Sect. 2.1 were critically evaluated. The first step consisted of evaluation of the historical credibility of the source. Primary sources were favoured, especially when the author was a direct eyewitness to the event described or prepared a report from a short chronological perspective or using older manuscripts. Secondary sources were used only after confirmatory comparison with primary records or if, from the spatio-temporal viewpoint, they accorded with other information. Historical place names for the locations to which the report or event described was attributed were updated to their recent equivalents and their exact positions were expressed in Fig. S1 in the Supplement. Any archaic terminology within the reports was translated into modern professional terminology. If a documentary source exists only as a manuscript or separate print in an archive or library, it is cited as an archival source (AS). If any of these archival documentary sources have already been the subject of professional attention and published, the corresponding reports are cited with respect to the related publication rather than the original archival source.

Because the documentary dataset from central Europe is huge, only certain selected reports were used to describe the general character of summers in individual years during the 1531-1540 period in central Europe (Sect. 4.1). In order to characterize European spatial precipitation and drought patterns for each summer, the above documentary-based descriptions were considered in the light of the corresponding European maps of JJA precipitation totals following Pauling et al. (2006), expressed as percentage deviations from the 1961-1990 mean, and in terms of JJA scPDSI from OWDA following Cook et al. (2015), in which negative values describe dry patterns, and positive values represent wet patterns (see Figs. 1-10). Mean SLP fields for individual summers in 1531-1540 were used to describe typical circulation patterns, together with their deviations from the 1961-1990 reference period over the Atlantic-European area (see Figs. 11-12).

To characterize JJA precipitation and drought patterns during the entire 1531-1540 decade, the corresponding gridded means of precipitation totals and scPDSI were calculated and expressed as deviations from the 1961-1990 reference period that indicated drier or wetter patterns (see Fig. 13). Precipitation and drought patterns were complemented by JJA temperatures taken from the European multi-proxy reconstruction by Luterbacher et al. (2004). To show the relationships of the above three variables to SLP patterns, their deviations from the 1961-1990 reference period were expressed with respect to SLP deviations (Fig. 14). Moreover, fluctuations in decadal means for the individual series investigated were expressed to put the decade analysed into the context of the last five centuries (see Fig. 15) and the 1531-1540 decade placed in order (from driest to wettest) within the entire series. This was based on series of JJA SPI, JJA SPEI, and JJA Z-index for the Czech Republic (Brázdil et al., 2016a); on JJA precipitation totals in central Europe after Pauling et al. (2006); and on JJA scPDSI and JJA Drought Area Index after Cook et al. (2015). The central European region was demarcated by $45-55^{\circ} \mathrm{N}$ latitude and $5-25^{\circ} \mathrm{E}$ longitude. The Drought Area Index (DAI) was defined as the percentage area presenting values below a given threshold (Bhalme and Mooley, 1980). DAI was calculated on the basis of OWDA, using http://drought.memphis.edu/OWDA/Default.aspx as an area with scPDSI less than or equal to -1 . Further, the dates upon which grain and grape harvests began in the Czech Lands, Austria, Switzerland, and France during 1531-1540 were included as proxy indicators of summer weather patterns (see Fig. 16).

\section{Results}

\subsection{Weather and related events of the individual summers in 1531-1540}

\subsubsection{Summer 1531 (Fig. 1)}

In early May 1531, the River Elbe flooded in Saxony, although no rain was reported (Weck, 1679). A relatively cold period lasting until Pentecost (7 June) was reported from Mühlhausen in Thuringia (AS9) and other parts of central Germany (Spangenberg, 1572). In Bohemia, after a delay in the hay harvest in the Louny region, the course of field labour in 1531 was evidently impaired by downpours in the week before 25 July; harvesters were paid for only a few days, when they dried wet hay. The bad weather appears to have continued for the 3 weeks after 22 August, in which field labourers were paid no wages at all (AS14). Severe drought around 2 September was reported in Red Russia and south-eastern Poland, associated with the apparition of a comet, indicating droughts in August (Kronika Marcina Bielskiego, 1764). Summer weather conditions in Switzerland were somewhat unsettled, with rain, hail, and thunderstorms in June, but there were also warm and sunny periods in July and then thunderstorms again in August (AS10). The grape harvest started on 5 October in the vineyards of the Vienna hospital in Austria (AS15). A good harvest of grain and grapes was mentioned for Litomerrice in Bohemia; the wine was described as "good" (Smetana, 1978). Extraordinary demand raised the barrel-price of wine in Litoměrice (ibid.). Plenty of wine, again considered "good" was reported for Würzburg (Fries, 1713; Engel, 1950), Schweinfurt (Mühlich and Hahn, 1817), as well as for Kitzingen in Franconia (Aldenberger, 1615) and Württemberg (Ginschopff, 1631), but also around Jena (Koch, 1928). Low wine prices are confirmed by a contemporaneous chronicler from Villingen (Roder, 1883). 

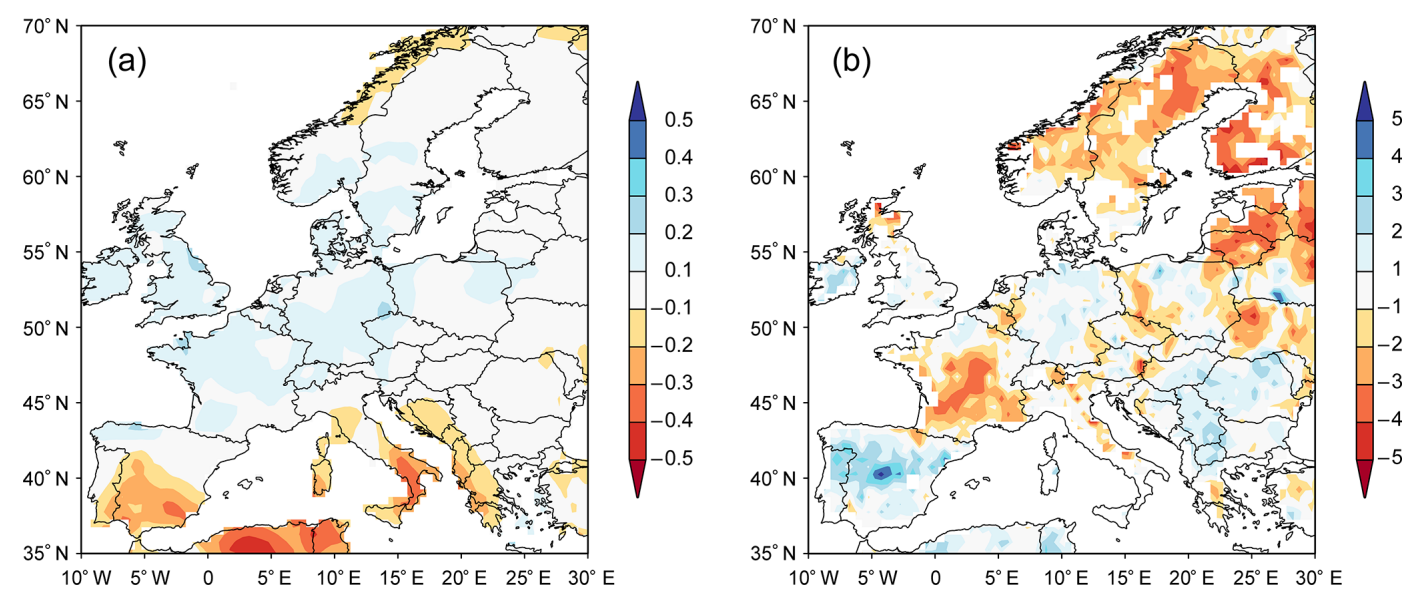

Figure 1. (a) The 1531 JJA precipitation totals in Europe expressed as percentage deviations $(\times 100)$ from the 1961-1990 mean (Pauling et al., 2006); (b) JJA scPDSI for 1531 in Europe according to OWDA (Cook et al., 2015).

In contrast, a bad harvest of grain and famine in Moravia are mentioned, without further specification (Steinbach, 1783), together with reports of a poor harvest (Dudík, 1868), while a severe shortage of grain is recorded by another source (Fischer, 1808). A severe shortage of grain was also mentioned in Silesian Wrocław by town scribe Nikolaus Pol (Büsching, 1819). High grain prices were reported for central Bohemia in the region around Říp Hill (AS6) and for Halle and its surroundings in eastern Germany (Spangenberg, 1572; Dreyhaupt, 1749), as well as for Mühlhausen in Thuringia (AS9). The same problems were noted for Dortmund (Hansen, 1887), Alsace, and Swabia (Spangenberg, 1572), particularly in Villingen (Roder, 1883). A dearth of hay occurred in the area of Zurich (Switzerland), and grain was very expensive there (Hauser, 1905).

\subsubsection{Summer 1532 (Fig. 2)}

Martin Leupold von Löwenthal, the town scribe for Jihlava (Moravia), reported that a dry period occurred between 17 March and 3 July 1532, when the rain hardly dampened the dust (d'Elvert, 1861). Although $4 \mathrm{~d}$ of rain (18-21 July) at comparatively higher altitudes ensured an adequate grain harvest, the dry spring and summer (ibid.) led to a bad harvest in both Bohemia (Tille, 1905) and Moravia (Dudík, 1868), for which Steinbach (1783) also mentions a dry year. In Trutnov (northern Bohemia), drought was recorded as so severe that fountains ran dry and fires broke out in the woods (Schlesinger, 1881). In the Louny region, the barley harvest was early, in the week before 25 June, although the wheat was harvested at the usual time (AS14). Records kept by Pankraz Engelhart from Cheb in western Bohemia (Gradl, 1884) may also be attributed to 1532, describing the year as dry, with a dearth of grain, when people starved to death (dated erroneously to 1531). A similarly bad harvest was reported in Germany by the Heinrich Hug chronicle, but the wine was good (Roder, 1883). A source from the Brandenburg area of Germany (Riedel, 1862) mentions intense dryness for many weeks; the soil was dry "knee deep". In Switzerland, the grain harvest was considered good, but a plague of mice destroyed it (Blumer, 1853).

A dry summer for 1532 was mentioned for Silesia, with no rain for 7 weeks; grass and standing crops withered. There was such a shortage of water that water-mills could not operate and people had to travel 10 to 18 miles (i.e. from ca. 66 to ca. $119 \mathrm{~km}$ ) to get their grain milled. The River Oława was without water up to 3 September. There were also fires in Silesian towns, noted for 31 July in Wrocław and 4 September in Legnica (Büsching, 1819). A severe shortage of grain in Těšín was recorded by Biermann (1863).

Gaspar Hain, in the Spiš area (Slovakia), recorded that there was no rain for 12 weeks between 3 April and 21 June: he mentions "great drought" in gardens, no grass in the meadows, no pasture for animals, and that water mills could not work. The grape harvest in Hungarian Tokaj was early (Bal et al., 1910-1913). However, according to the daily reports of Emperor Suleiman, August, and probably also July, could have been rainy in Hungary (Thúry, 1893).

\subsubsection{Summer 1533 (Fig. 3)}

A chronicler for Bohemia records 13 floods before 3 July for Prague, and then another one (Zilynskyj, 1984). In the Louny region, the year was more or less average for work in the fields (Brázdil and Kotyza, 2000). In the week before 8 July, however, wages were paid to labourers who "pulled hay out of the water" (AS14, fol. 173v). It appears to have been rainy in the week before 22 July as well, when wages were paid "for turning wheat shocks" and in the 2 subsequent weeks with wages "for spreading grain to dry and making new shocks" (ibid., fol. 174r) and for "spreading rye to dry" (ibid., fol. 174v). Jan z Kunovic, in his intermittent daily 

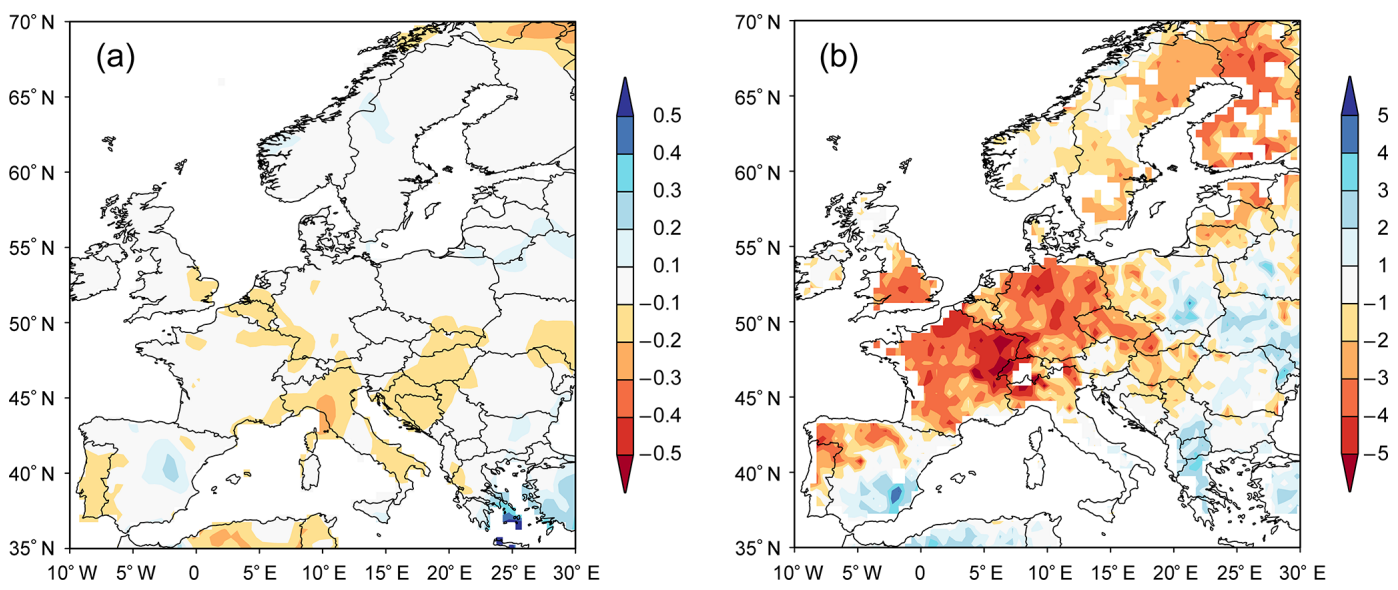

Figure 2. (a) The 1532 JJA precipitation totals in Europe expressed as percentage deviations ( $\times 100)$ from the 1961-1990 mean (Pauling et al., 2006); (b) JJA scPDSI for 1532 in Europe according to OWDA (Cook et al., 2015).

records, notes rain on 24-26 and 28 July (Brázdil and Kotyza, 1996). The source from Jihlava records severe shortages despite a good harvest of grain (d'Elvert, 1861). According to surviving data in the Vienna hospital accounts (AS15), the dates for the grain harvest (10 July), oat harvest (4 August), and grape harvest (10 October) were the latest of the decade. A wet June and July are mentioned in a report from Kraków (Poland) where, after persistent rains, the River Vistula flooded for the seventh time that year, between 17 July and 1 August (Maurer, 1878). The Silesian chronicler Michael Steinberg (Schönborn, 1878) describes the summer as wet, with frequent thunderstorms and hailstorms that damaged the grain. The story is the same from Wrocław town scribe Nikolaus Pol who, in addition, mentions subsequent famine and a disastrous flood on 21-29 June on the River Oder (Büsching, 1819).

Southern German sources refer to 1533 in general as a "cold and infertile year" (Ginschopff, 1631), they also report sour wine from the Breisgau and a lack of grain all over south-western Germany (Roder, 1883). Further afield, the water level of the River Rhine at Basel appeared to be high in March, April, and June (Fouquet, 1999). Other Swiss sources describe periods of rainfall that damaged the grain in the fields, even leading to shortages (AS10; Blumer, 1853).

\subsubsection{Summer 1534 (Fig. 4)}

The barley harvest in the Louny region started very early in 1534, during the week before 23 June (AS14), but haymaking and the harvest of other cereals took place around the usual times (Brázdil and Kotyza, 2000). Harvest work finished early, in the week before 11 August. The peas were picked almost immediately after this, and the hemp and millet were harvested similarly early (ibid.). The summer proper was considered disastrously dry, with a lack of fodder for cattle and little water in the Elbe and Vltava rivers, but there was a good harvest of grain (Smetana, 1978; Kolár, 1987). After 3 months of drought, the water in the River Vltava was so low that people could walk across its bed (AS3). The fruit and grape harvests were good, and the year's wine was judged "good" (d'Elvert, 1861; Smetana, 1978). The Vienna hospital accounts indicate that the grain harvest started on 5 July, oats on 30 July and grapes on 2 October (AS15). According to tithe payments, there was quite a good grape harvest in Sopron (Hungary) (AS2).

A severe lack of water, continuing until 1535, was reported in the Brandenburg area, leading to high prices and shortages (Engel, 1598; Riedel, 1862). Hordes of caterpillars appeared in response to the drought. The weir at Jena could be crossed on foot (Koch, 1928). Low water levels and milling problems are known for Schweinfurt on the River Main (Mühlich and Hahn, 1817). Mansfeldische Chronica describes the summer as hot and very dry, due to which the grass in the fields and the leaves on the trees dried out. The lack of water also made it difficult to find functioning watermills to grind grain (Spangenberg, 1572). Dietrich Westhoff, a chronicler from Dortmund, reported an extremely hot summer and associated it with several city fires, including a blaze in Montabaur (Werlich, 1595; Hansen, 1887). The connection between drought and fires in central Germany was also made by Spangenberg (1572). There were reports of a very warm summer in the Zurich area (AS10).

A hot, dry summer in Silesia is also on record, the season lasting from 15 April until 3 September. Streams dried up, mills could not operate and famine followed (Gomolcke, 1737). This was confirmed by reports of the River Oder drying up and the use of horse- or hand-mills to grind grain (Kundmann, 1742). Grain sprouted on 25 April and there was a good yield of cherries, but spells of great heat led to fires (Büsching, 1819). Similarly, the hot summer presaged a lack of grain and fodder in Lusatia and water mills could not operate (Roch, 1687; Gomolcke, 1737). 

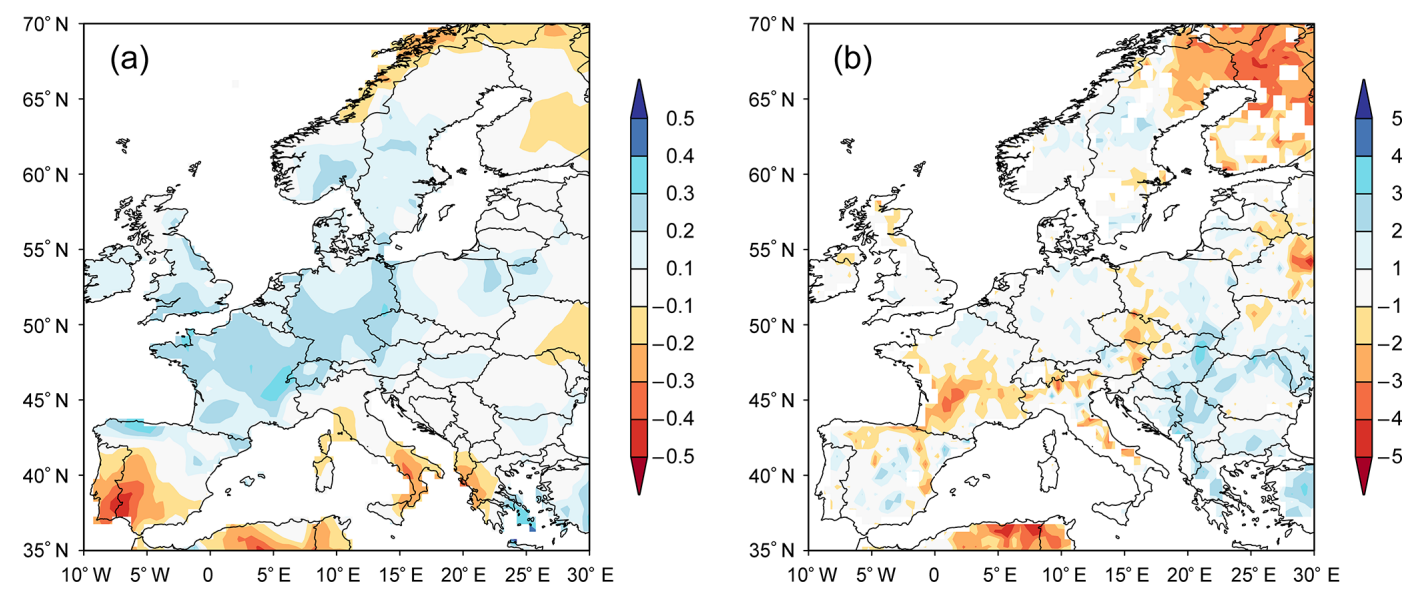

Figure 3. (a) The 1533 JJA precipitation totals in Europe expressed as percentage deviations $(\times 100)$ from the 1961-1990 mean (Pauling et al., 2006); (b) JJA scPDSI for 1533 in Europe according to OWDA (Cook et al., 2015).
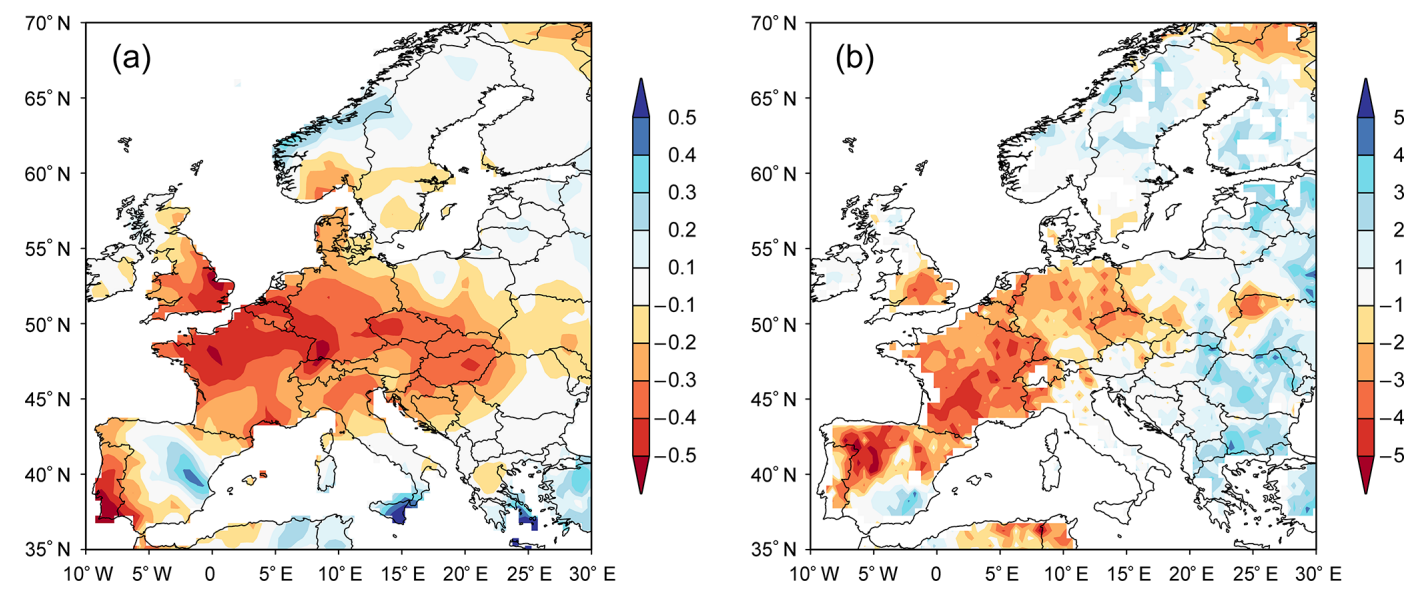

Figure 4. (a) The 1534 JJA precipitation totals in Europe expressed as percentage deviations $(\times 100)$ from the 1961-1990 mean (Pauling et al., 2006); (b) JJA scPDSI for 1534 in Europe according to OWDA (Cook et al., 2015).

In contrast, Lesser Poland saw floods after some days of rain, occurring on 11-12 July on the rivers Dunajec and Kamienna, as well as on the Vistula at Kraków (Kętrzyński, 1888). South-western Germany reported a good grain harvest (Ginschopff, 1631) and floods on the rivers Wertach and Lech south of Augsburg (Werlich, 1595). Flood damage was also reported in central and southern Transylvania (Trauschenfels, 1860; Szilágyi, 1893). High prices prevailed in Transylvania (Trausch, 1847; Gross and Seraphin, 1903a). Based on another contemporary local chronicle, severe food shortage and hunger occurred in Sibiu (Vereins-Ausschuß, 1851). Historical memories from the 17 th century indicate that this dearth lasted for over 3 years (Barabás, 1880).

\subsubsection{Summer 1535 (Fig. 5)}

Bohemia was reported as hot and dry, with the streams drying up and frequent forest fires (AS7). This pattern appears to be confirmed by field labour in the Louny region, where the harvest started in the week leading up to 22 June, i.e. as early as in 1534. Haymaking took place, as usual, in the following week. The rye harvest started in the week before 29 June and was possibly the earliest for this crop in the entire 16th century. A very early start to the harvest was also recorded for wheat (in the week before 13 July) and for oats (in the week before 3 August). The harvest was over very early, in the week before 10 August (AS14). The Vienna hospital accounts report the beginning of grain harvest as 2 July and the grape harvest as 3 October (AS15).

In Silesia, the drought brought suffering to both people and livestock. Water mills could not operate for 10 weeks for sheer lack of water. The harvest of winter grain was average and that of summer grain was very bad (Büsching, 1819). A week of rainy spells starting on 25 August led to a flood on the Vistula in Lesser Poland (Maurer, 1878). Brandenburg reported an extremely hot summer (Riedel, 1862). 

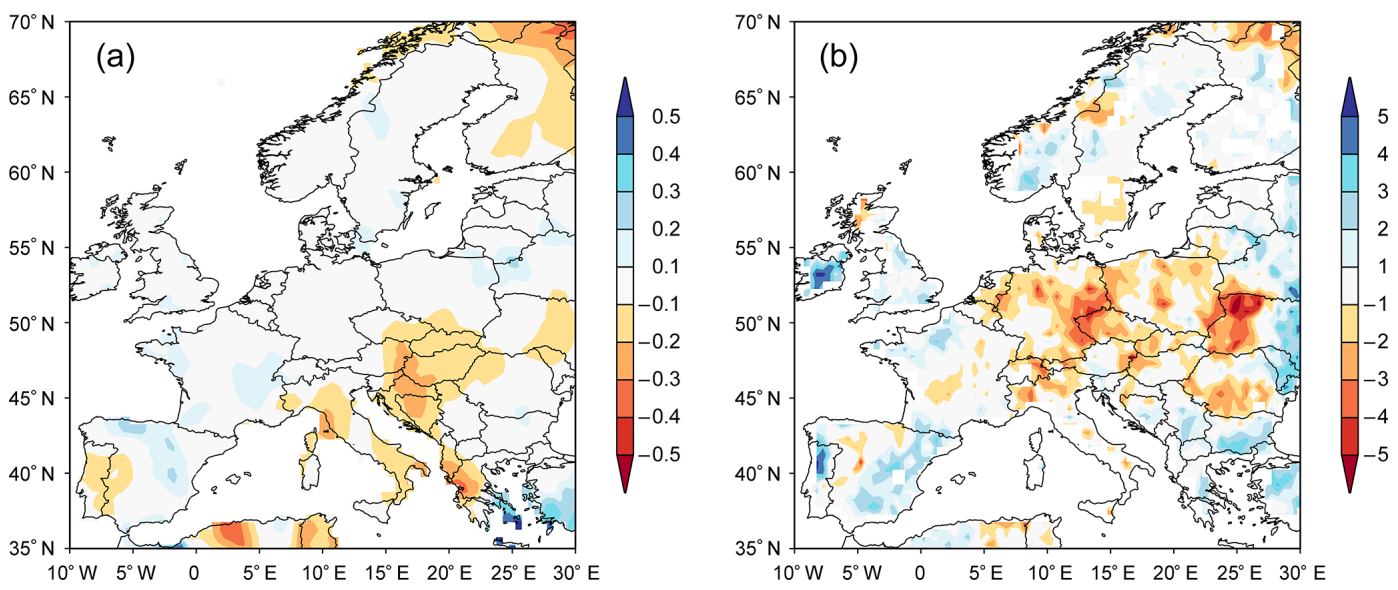

Figure 5. (a) The 1535 JJA precipitation totals in Europe expressed as percentage deviations ( $\times 100)$ from the 1961-1990 mean (Pauling et al., 2006); (b) JJA scPDSI for 1535 in Europe according to OWDA (Cook et al., 2015).

In Basel, according to the chronicle of Konrad Schnitt, the summer began with warm and dry weather, but the weather changed in the middle of August and a rainy period followed, lasting until November. Nonetheless, it was a productive year with very good grape and grain harvests (Bernoulli, 1902). This is confirmed by historiography from around Stuttgart (Ginschopff, 1631). In the Mansfelder Land area, west of Halle, harvests were bountiful and grain prices plummeted to a fifth of what they had been in winter (Spangenberg, 1572). In Arnstadt, Thuringia, the grape harvest was plentiful (Olearius, 1701), as was the grain harvest in Mühlhausen (AS9). However, much of this was spoiled in Jena by a plague of caterpillars (Koch, 1937).

There are undated reports of floods in southern Transylvania to be found in the contemporaneous chronicle of Hieronymus Ostermayer: the flooded River Olt damaged Turnu Rosu Castle and the River Ghimbav did great damage in the Braşov area (Gross and Seraphin, 1903b).

\subsubsection{Summer 1536 (Fig. 6)}

Summer 1536 was very dry in Bohemia and the water in the River Elbe was low. Considerable damage was done by an eruption of caterpillars. Roses blossomed twice (AS12; Smetana, 1978; Zilynskyj, 1984). Pankraz Engelhart and Andreas Baier (Gradl, 1884) speak of a summer drought and heat in Cheb, together with frequent fires in forests and settlements. Marek Bydžovský z Florentina (Kolár, 1987) mentions dry weather, with wells and streams drying up and frequent fires from April to Christmas. In the Louny region, the timing of field labour did not differ conspicuously from the average, with the exception of mowing the aftermath, which was delayed to the week before 3 October (AS14). The Vienna hospital accounts indicate that the harvest of grain started on 2 July, of oats on 3 August, and of grapes on 6 October (AS15). Although vineyards froze on 2 May around the town of Litoměrice (AS12), there was "enough" good wine, whereas there was a poor grape harvest in Moravia (Smetana, 1978). Ample good wine (see also Kolár, 1987), fruit, and nuts are mentioned by Cheb chronicler Pankraz Engelhart, but there was also a dearth of grain after a poor harvest (Gradl, 1884).

Several sources report a dry summer for Germany. Such reports come, for example, from Meissen ("an exceedingly dry summer", AS8, p. 188; confirmed for Dresden by Weck, 1679), Mansfeld (Spangenberg, 1572), Regensburg (Freiherrn von Oefele, 1878), Kitzingen (Aldenberger, 1615), and Halle (Dreyhaupt, 1749). However, the grain harvest was good in Saxony (Knauth, 1722). A hot summer was reported in Stuttgart, with dried-up wells and brooks and a lack of water for people, livestock, and milling (Ginschopff, 1631). Problems with milling during the dry summer were reported in Erfurt and the municipality decided to provide Rossmühle, i.e. mills run by horses (von Falckenstein, 1738). In Jena, a single day of rain in May was worth reporting, since it was the first of the year (Koch, 1937). Sources in Pomerania and Silesia reported frequent thunderstorms with torrential rains and related damage, particularly in June-July (Gomolcke, 1737; Hubatsch and Arnold, 1968).

Basel chroniclers report a prevalence of very warm and dry patterns during the summer. The vintage was therefore very good and the wine prices low. However, there was a dearth of hay and lack of fodder for the cows led to a shortage of butter (Vischer and Stern, 1872; Bernoulli, 1902). The chronicler Hans Salat described very dry weather conditions in central Switzerland, where water mills could not operate for a long time for lack of water, although an abundant harvest was mentioned for the region (Baechtold, 1876). 

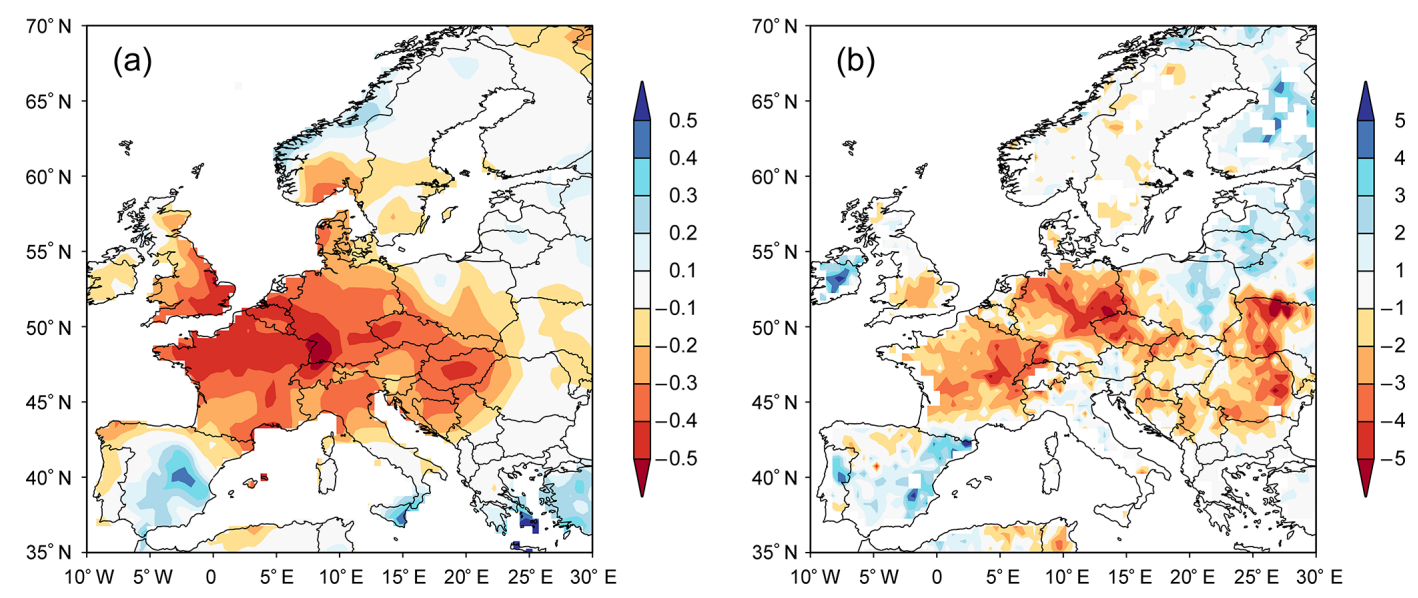

Figure 6. (a) The 1536 JJA precipitation totals in Europe expressed as percentage deviations ( $\times 100)$ from the 1961-1990 mean (Pauling et al., 2006); (b) JJA scPDSI for 1536 in Europe according to OWDA (Cook et al., 2015).

\subsubsection{Summer 1537 (Fig. 7)}

Wet patterns in central Germany started with several days of rain and subsequent flooding of the River Saale at Jena, starting on 9 May (Koch, 1937). Rain and flooding continued throughout May (Roch, 1687; Müller, 1806; Koch, 1937). In Bohemia, floods after $3 \mathrm{~d}$ of rain were reported from 30 May to 1 June. These culminated with considerable damage on 2 June (AS5; Zilynskyj, 1984). Similarly, a flood was recorded on 30-31 May on the Lusatian Neiße (Nysa), when it did considerable damage to the town of Görlitz in Saxony (Müller, 1806; Struve, 1870) and other places (Rojecki et al., 1965). The summer of 1537 was described as wet in Varnsdorf (Bohemia), and the grain grew well (Palme, 1913). This concurs with similar records for Silesia. There are further confirmations of a wet summer, with reports of periods of continuous rain and flooding for June and July from Wrocław (Büsching, 1819). In the Louny region, the beginning of work in the fields took place at the usual time, with the exception of the hemp harvest (Brázdil and Kotyza, 2000). The start of haymaking in the week before 3 July was evidently affected by rain because "when raking the hay, everything was soaked with water" (AS14, fol. 223v). The haymaking and the harvest were interrupted in the week before 7 August, apparently due to rain because no wages were paid for field labour during that time (AS14). The Vienna hospital accounts indicate the dates upon which harvests started: grain on 6 July, oats on 29 July. and grapes on 2 October (AS15).

A parallel finding consists of reports of many thunderstorms during summer 1537 in Saxony (Roch, 1687). For central Germany, Mansfelder Chronik reports continuous rain in June (Spangenberg, 1572), and further flooding in the town of Görlitz in Saxony (Müller, 1806) and in Jena (Koch, 1937). At the end of June, it was so cold that people started to use their ovens for heating (AS9; Spangenberg, 1572). Andreas Baier in Cheb described the whole year of 1537 as wet
(Gradl, 1884). In central Switzerland, after a rainy May, the wheat and oat harvests were good, as were those of cherries and apples (Baechtold, 1876). A rainy June with flooding and a cold summer are mentioned in German sources for Mansfeld (Spangenberg, 1572), as well as for Regensburg (Freiherrn von Oefele, 1878) and for Jena (Koch, 1937). Floods were also reported in the north of Germany (Lappenberg, 1861). A good harvest of crops and fruit was observed around Stuttgart (Ginschopff, 1631).

\subsubsection{Summer 1538 (Fig. 8)}

A hot, very dry summer occurred in Bohemia, with forest fires in places (AS7; Gradl, 1884), and in the Erzgebirge mountain range as well (Arnold, 1812). The dry weather evidently led to a dearth of grain mentioned by Johann Mathesius (AS4). The water in the River Elbe was so low that the bed could be crossed on foot and by cart. In the Louny region, the harvest started early, in the week before 25 June (AS14). The wheat harvest began in the week before 9 July, the earliest recorded for this crop in the 16th century. The peas also ripened very quickly indeed and were already being gathered in the week before 23 July; accelerated in similar fashion, the oat harvest began in the following week and ended in the week before 13 August (AS14). Grapes started to soften on 9 July and the vintage began before 11 September (Smetana, 1978). Ample good wine was reported (Rezek, 1879). The Vienna hospital accounts indicate harvest dates for grain starting on 6 July and grapes on 5 October (AS15).

The summer in Dortmund (Germany) was described as hot, with a negative effect on crops (Hansen, 1887). Michael Steinberg in Silesia mentions spells of heat before 19 June and an early harvest on 3 July (Schönborn, 1878). In eastern Pomerania there was "nearly no water" in the River Vistula (Henneberger, 1595; Curicke, 1688). It was a productive year in Transylvania and prices were low (Gross and Seraphin, 

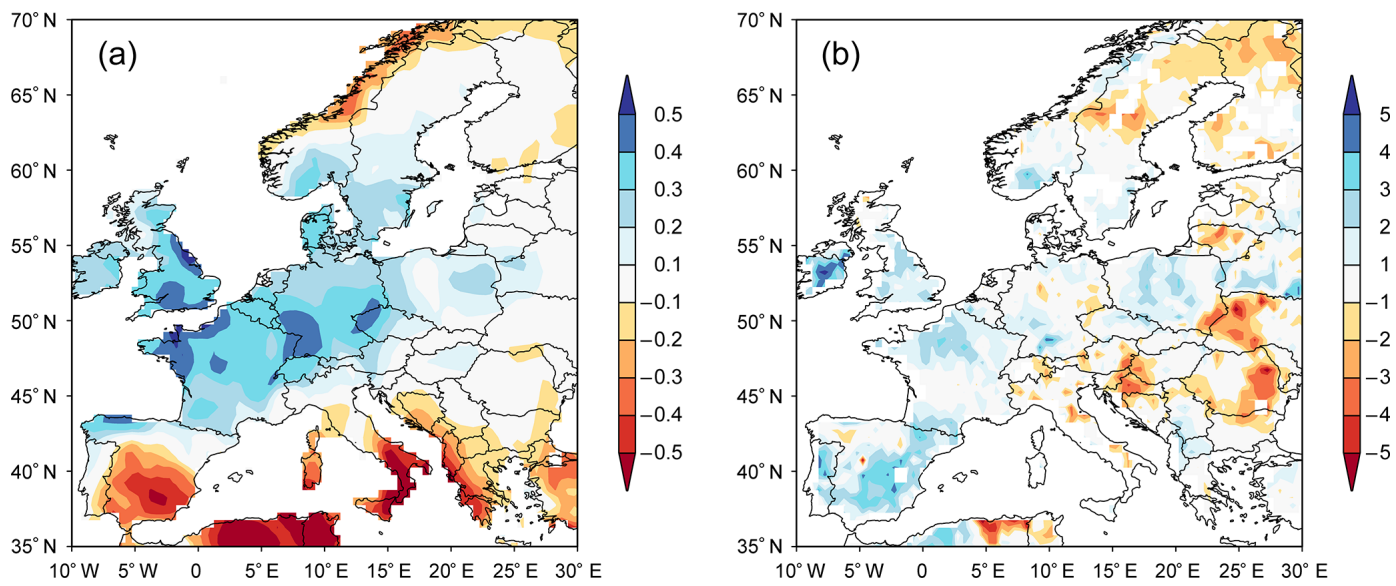

Figure 7. (a) The 1537 JJA precipitation totals in Europe expressed as percentage deviations ( $\times 100)$ from the 1961-1990 mean (Pauling et al., 2006); (b) JJA scPDSI for 1537 in Europe according to OWDA (Cook et al., 2015).
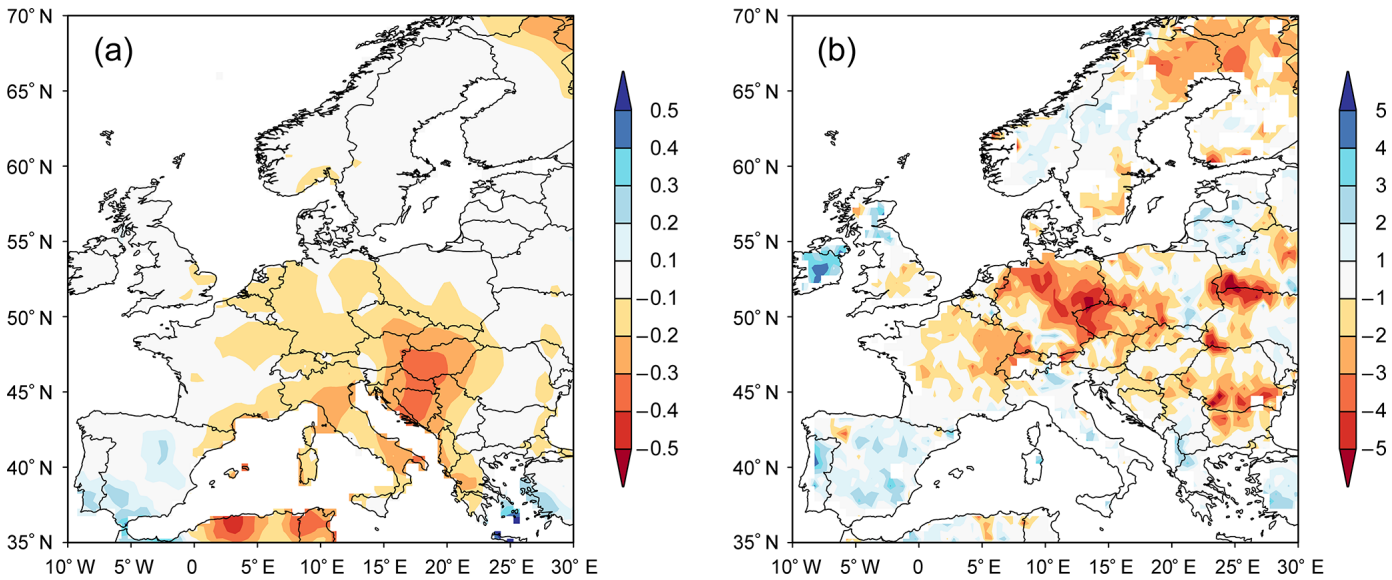

Figure 8. (a) The 1538 JJA precipitation totals in Europe expressed as percentage deviations $(\times 100)$ from the 1961-1990 mean (Pauling et al., 2006); (b) JJA scPDSI for 1538 in Europe according to OWDA (Cook et al., 2015).

1903b; Armbruster, 1984). This was probably the case in other parts of the Carpathian Basin as well (Horváth, 1868; Weber, 1894).

\subsubsection{Summer 1539 (Fig. 9)}

The chronicler Pavel Mikšovic recorded a flood at Louny after a cloudburst on 24 July (AS13). In the same region, much of the harvest came in very early: the haymaking; the general harvest; and the rye, oats, hemp, and millet (Brázdil and Kotyza, 2000). In addition to satisfactory harvests of grain, vegetables, and fruit, narrative sources also mention ample good wine (d'Elvert, 1861; Smetana, 1978). A Silesian source refers to a pleasant, dry harvest (Büsching, 1819). Vienna hospital accounts indicate harvest dates starting on 5 July for grain, 24 July for oats, and 4 October for grapes (AS15).

From the intermittent daily weather records kept by Jan $\mathrm{z}$ Kunovic, there is a note for 23 August ("rain up to this point") and heavy rain fell on 26 August (Brázdil and Kotyza, 1996). This spell of rain may have been responsible in part for five large floods on the River Saale recorded for Jena (Koch, 1928, 1937). One of these had already occurred on 6 August (Koch, 1937). Only a day later, on 7 August, there was a major flood in Meißen, Thuringia, and Franconia (Aldenberger, 1615). Summer 1539 in Meißen was marked by a dearth of grain (Weck, 1679), and a similar situation prevailed around the Harz mountains (Spangenberg, 1572) and again in Jena (Koch, 1937). For Erfurt, the von Falckenstein (1738) chronicle reports sour wine because of a wet autumn and too little sunshine in summer. Intense heat occurred in Jena, around 2 July (Koch, 1937). Farther west, in Trier, the grape harvest was reportedly abundant, as was the wine from it (Zenz, 1962). The same is known of Nürnberg (Aldenberger, 1615). This contrasts strongly with information from Dortmund (Hansen, 1887) that indicates a dearth of grain and outright famine there. Ginschopff's chronicle 

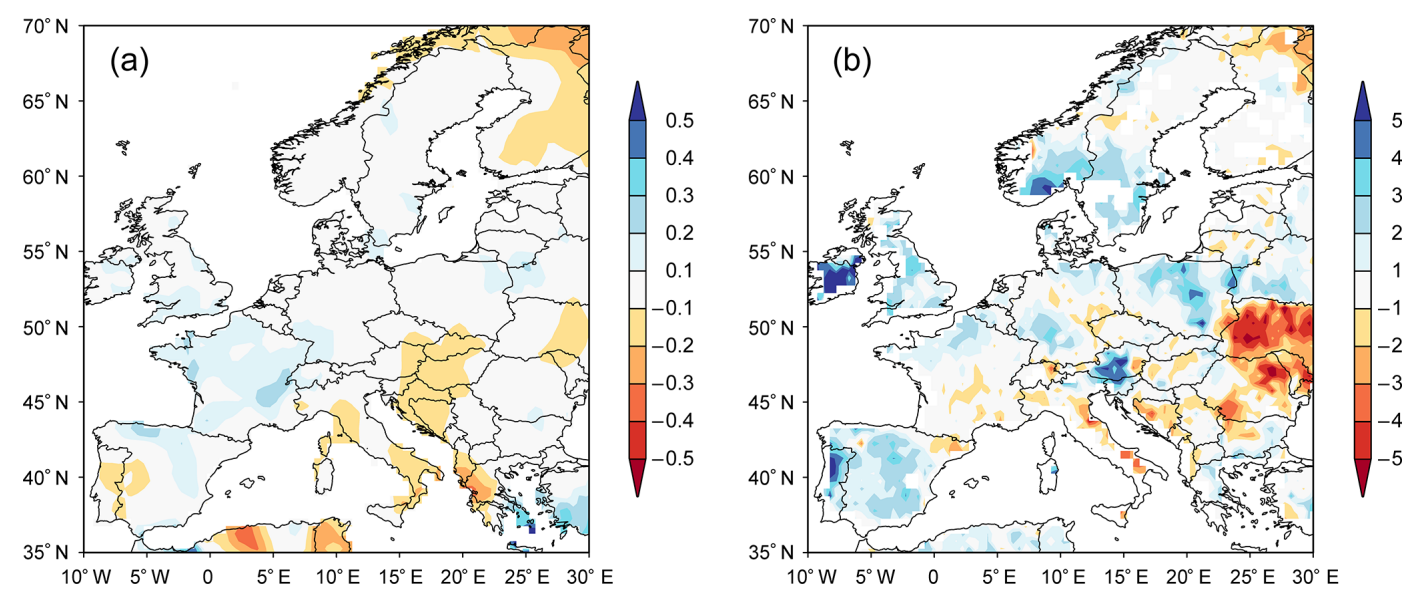

Figure 9. (a) The 1539 JJA precipitation totals in Europe expressed as percentage deviations $(\times 100)$ from the 1961-1990 mean (Pauling et al., 2006); (b) JJA scPDSI for 1539 in Europe according to OWDA (Cook et al., 2015).

(1631) reports good harvests after an average summer. In Switzerland, the grain and the grape harvests were good as well (AS10; Baechtold, 1876). The Ostermayer chronicle mentions relatively low cereal and wine prices in this year for Transylvania (Gross and Seraphin, 1903b).

\subsubsection{Summer 1540 (Fig. 10)}

Documentary sources in Bohemia speak above all of a hot, dry summer, shortages of water, and forest fires (AS4; AS7; AS13; Dudík, 1858; d'Elvert, 1861; Kolár, 1987). In the surroundings of Jihlava, a dry period with bad yields of vegetables and beets is recorded from 6 April until the end of the year. The harvest started before 9 July and grain crops were cut before 11 August (d'Elvert, 1861). Very dry and warm conditions with severe shortages of grain and vegetables occupied much the same time period in Uherský Brod (Zemek, 2004). Pavel Mikšovic (AS13) relates that a hot, dry period lasted from 26 May to 13 October, with rain only on 8 August and warm weather until the end of the year. In Cheb, Pankraz Engelhart (Gradl, 1884) speaks of a dry year, in which sowing and work in the fields went right on until the end of the year. Andreas Baier (ibid.) mentions a dry summer and warm weather until the end of the year. For the Louny region, the very earliest starts to the harvest were recorded: the beginning and the end of the harvest (in the weeks before 22 June and 3 August, respectively), the barley harvest (the same as for the general harvest), oats (in the week before 20 July), and peas (in the week before 13 July) (AS14). The grain harvest is described as "poor" (Gradl, 1884; Kolár, 1987), through "medium" (AS7), and up to "ample" but with poor yields of other crops (Rezek, 1879). The year 1540 was an excellent year for wine in Bohemia, with an abundant harvest of grapes (AS7; AS11; d'Elvert, 1861).

Severe heat and drought in summer and autumn afflicted Silesia, where there was practically no rain for 6 months.
Many streams dried up and the water in the River Oder turned green. There were frequent forest fires and livestock suffered from hunger and thirst (Büsching, 1819). Similarly, severe heat, forest fires, poor harvest, shortages, and famine were mentioned for Bohemia, Silesia, and Lusatia (Gomolcke, 1737). In Greater Poland, summer and autumn were also very dry; it did not rain until the beginning of winter. Rivers were exceedingly low, brooks, ponds, and wells dried up and the land was desiccated to dust (Rojecki et al., 1965). A hot summer with dried-up ponds, and cattle needing to be moved great distances for water, as well as poor growth of cereals were reported for Pomerania and eastern Prussia (Hubatsch and Arnold, 1968).

Gastainerische Chronica (Rohr, 2007) mentions warm, dry weather from the end of March to mid-August, with a very bad grain harvest and dried-up springs and brooks in the Salzburg area of Austria; forest fires were reported for Carinthia. The Vienna hospital accounts indicate quite an early start to the grape harvest, on 25 September, and the oats harvest beginning on 29 July. The grain harvest, which started on the particularly early date of 26 June, was the earliest of all the documented grain harvests of the century (AS15; Kiss, 2018). Fabricius (AS8) confirms a very warm and dry summer in Meissen; there was plenty of wine but a lack of garden produce. A report from the Brandenburg area mentions a very hot summer, during which forests were on fire in many places and waterways dried up, but the wine was good (Riedel, 1862).

Several Swiss sources remark upon a notably hot, dry year. In the Lucerne area, the dry weather led to many forest fires. Water levels were low and some fountains even dried up (Baechtold, 1876). In Basel, according to chronicler Fridolin Ryff, it did not rain more than three times between the beginning of summer and November and therefore many water mills could no longer operate. Moreover, water levels were low everywhere; it was even possible to ride or walk across 

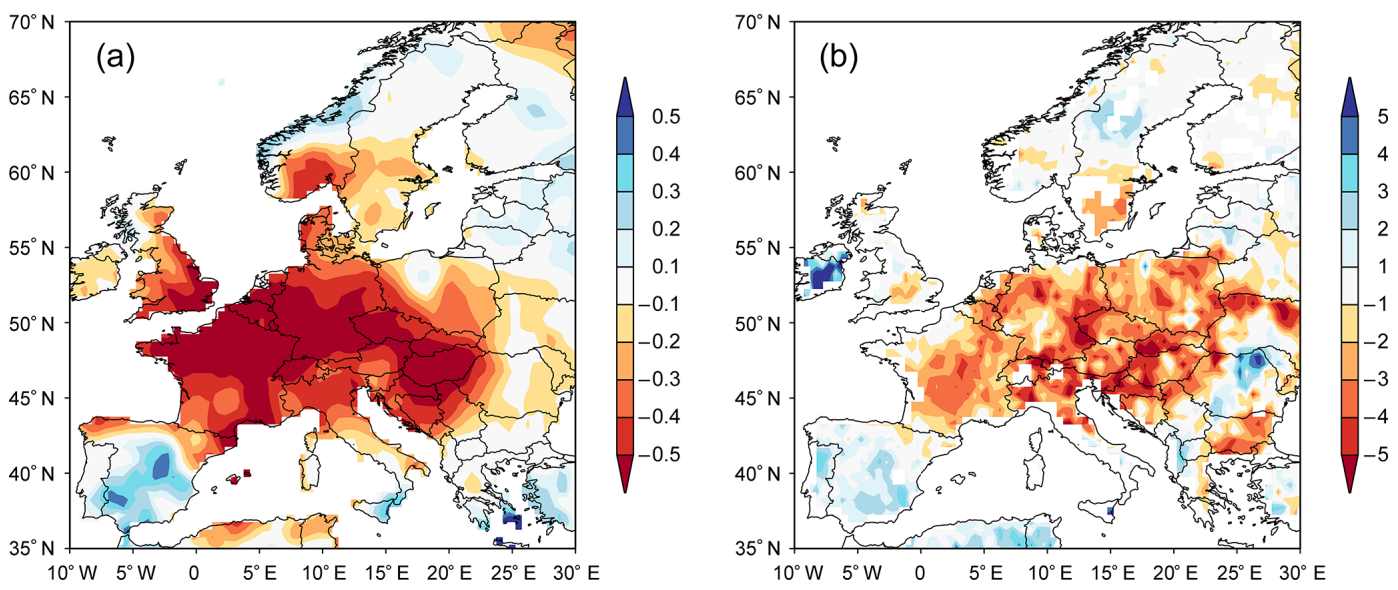

Figure 10. (a) The 1540 JJA precipitation totals in Europe expressed as percentage deviations ( $\times 100)$ from the 1961-1990 mean (Pauling et al., 2006); (b) JJA scPDSI for 1540 in Europe according to OWDA (Cook et al., 2015).

the River Rhine. The wine, fruit, and grain harvests were abundant (Vischer and Stern, 1872). In Zurich, the heat lasted from the end of February until mid-September, and not more than $6 \mathrm{~d}$ of rain occurred during this period. The water levels were so low that mills could not operate, and water for livestock had to be carried great distances in barrels. Nonetheless, the year was productive (Egli, 1904). In the north-east of Switzerland, the soil looked burnt by the drought, and wells and fountains dried up. Mills could not operate either, while trees suffered great damage due to lack of water (Baechtold, 1906).

A contemporaneous calendar inscription from Transylvania suggests that the solar eclipse on 17 April 1540 was followed by great heat, when many springs dried up, while in other places forest fires occurred (Schuller, 1848). Writing at the time, the historian Ambrus Somogyi, among others, also referred to a hot midsummer period (Simigianus, 1800). In the town accounts for Braşov, fires were mentioned twice, in summer and autumn (Rechnungen, 1889).

\subsection{Circulation patterns in the summers of $1531-1540$}

SLP maps may be used as indicators of possible circulation patterns in the decade studied. The mean JJA SLP field in the Atlantic-European area during the 1961-1990 reference period, together with deviations for the individual summers of 1531-1540 with respect to this reference, appear in Fig. 11. Mean JJA SLP field in the reference period shows the strong Azores high south-west of Europe with its ridge of high pressure extending to central Europe (Fig. 11a). Low pressure is especially evident in the south-eastern Mediterranean and adjacent land area. In terms of SLP deviations in the individual summers of 1531-1540 (Fig. 11b), drier summers in central Europe correspond with pressure increases over the European land mass and decreases over the Atlantic Ocean. The cores of pressure increases are especially marked over south- western Scandinavia $(1534,1536$, and 1540) and extend from there to central Europe (1532 and 1535). In the dry summer of 1538 , positive increases run from the south-west to the north-east (with the core region extending from the British Isles to south-western Scandinavia), with one arm continuing to Scandinavia and a second arm reaching central and south-eastern Europe. In somewhat wetter ("normal") summers, marked pressure decreases make up a dominant belt extending from the British Isles to central and south-eastern Europe $(1531,1533,1537)$. SLP for summer 1539 indicates quite positive NAO patterns: pressure decreases south of Iceland and increases south-west of the Iberian Peninsula.

In general, the mean patterns for summer 1531-1540 (Fig. 12a) are similar to those for mean JJA SLP field in the reference period (Fig. 11a). Their deviations with respect to 1961-1990, however, are more interesting (Fig. 12b). The border between negative and positive pressure deviations tends to extend from the north-west (east of Iceland) to the south-east (central Mediterranean) and divides the AtlanticEuropean area into two parts. The decreases in SLP are located west of this border and the majority of them are statistically significant (particularly in the central part of the Atlantic and in the Iberian Peninsula), while pressure increases occur towards the east, again at their highest in Scandinavia and lower in central and southern Europe.

While SLP fields explain the exceptional character of the 1531-1540 summers clearly, the summer index of the North Atlantic Oscillation (NAO), reconstructed by Luterbacher et al. (2002a), achieves only slightly positive values (not shown). They show no significant deviation from the previous or subsequent decades; in fact, they tend to decrease from positive values at the beginning of the 16th century to negative thereafter. 
(a)

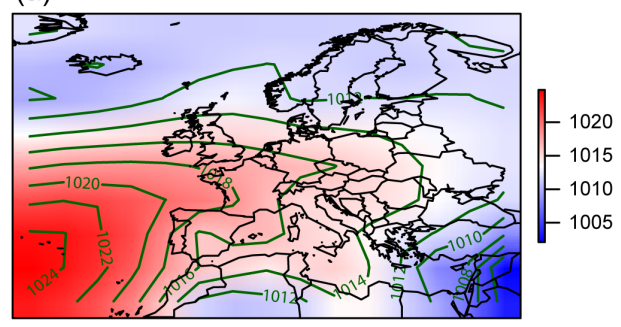

(b)

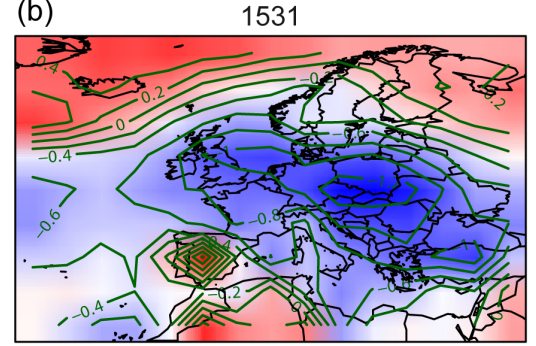

1533

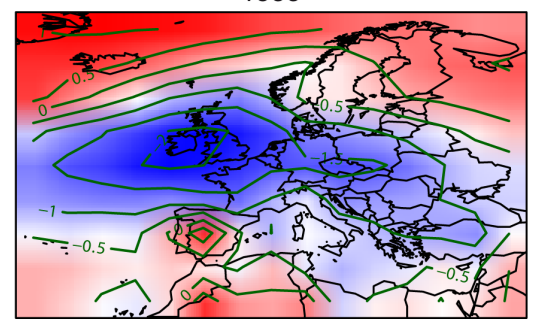

1535

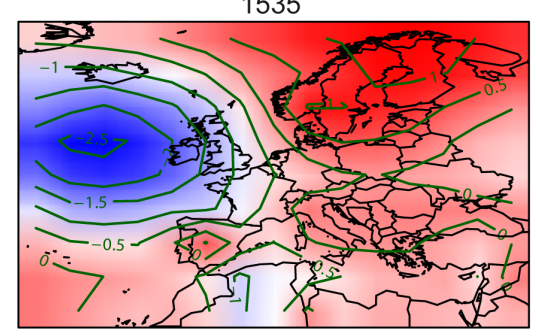

1537

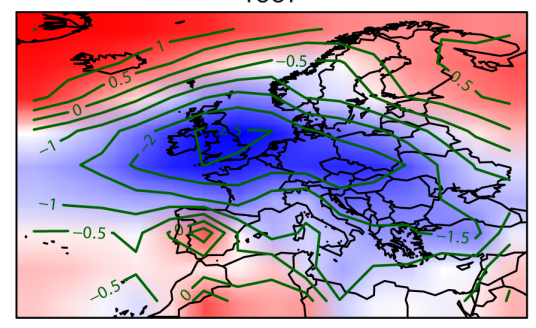

1539

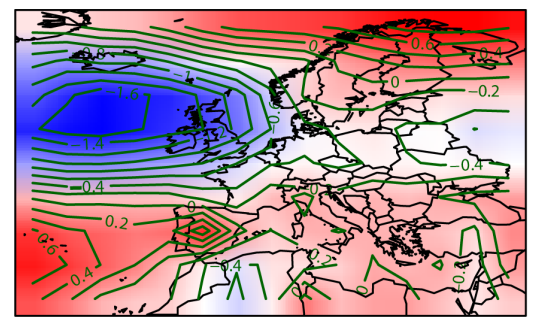

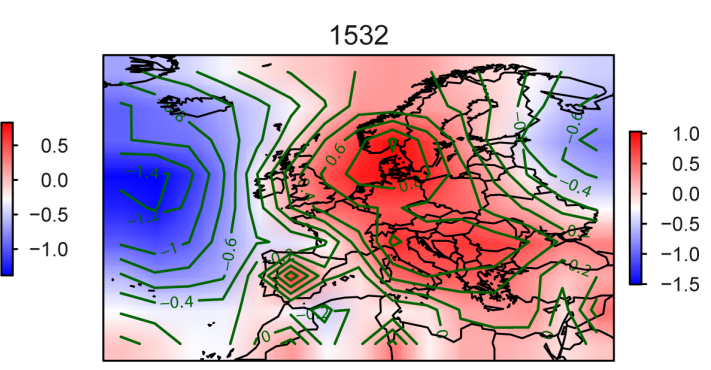

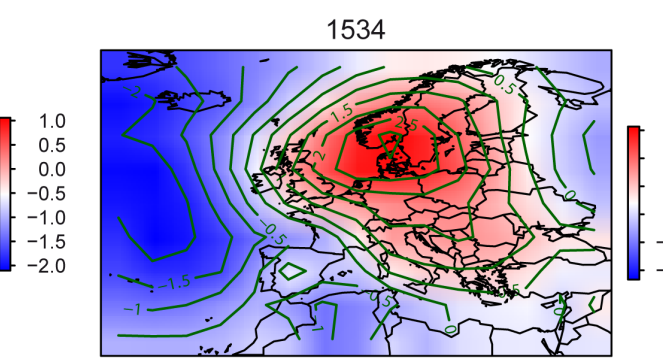

1536
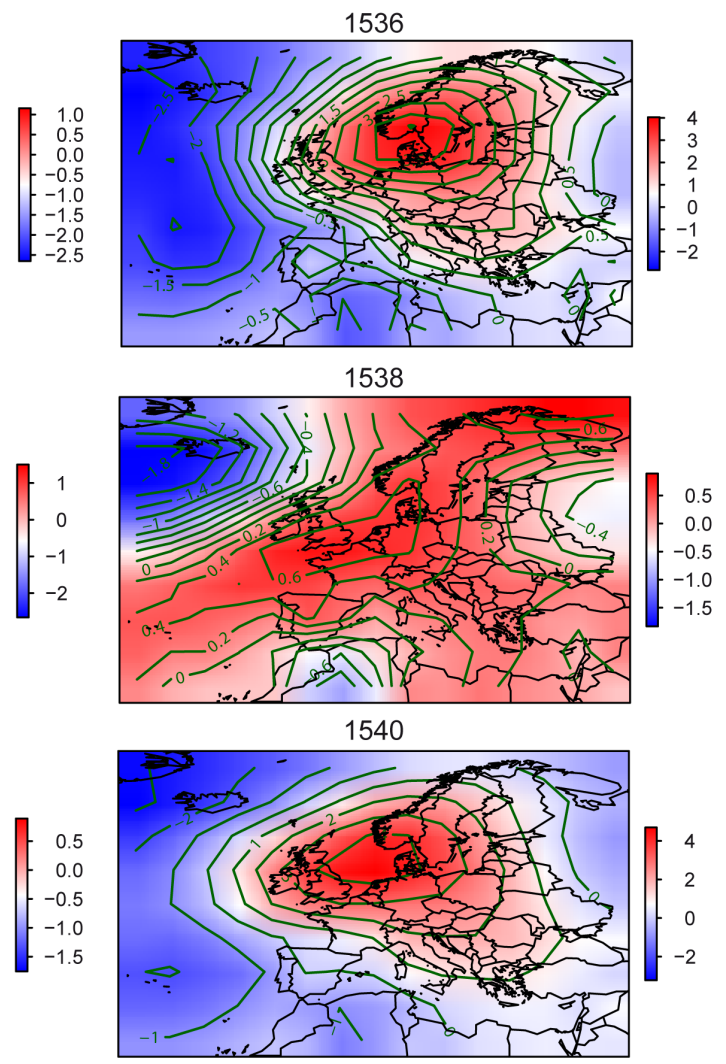

Figure 11. (a) Mean JJA SLP field in the Atlantic-European area during the 1961-1990 reference period and (b) anomalies in the mean SLP fields of the individual summers in 1531-1540, based on data from Luterbacher et al. (2002b) (available at https://www.ncdc.noaa.gov/ paleo-search/study/6366). 
(a)

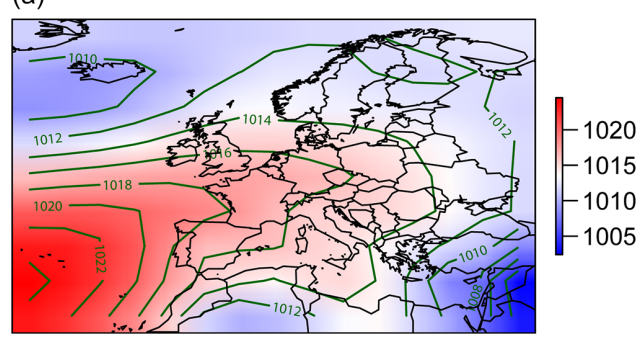

(b)

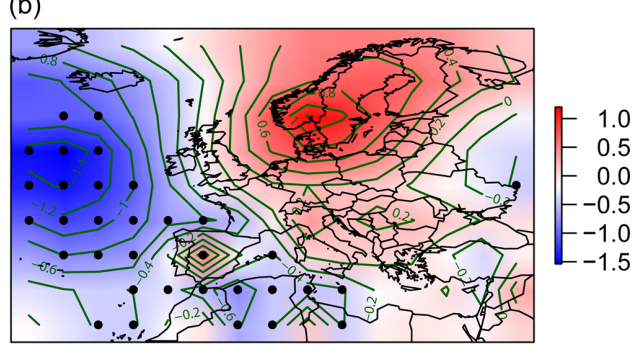

Figure 12. Mean JJA SLP field for 1531-1540 (a) and deviations from the 1961-1990 reference period (b) in the Atlantic-European area. Points indicate grids with statistically significant deviations at a significance level of 0.05 .

\subsection{Hydroclimatic variability of the 1531-1540 summers in longer-term context}

The spatial precipitation, drought, and air temperature patterns of the 1531-1540 summers, with respect to the summers in the 1961-1990 reference period in central Europe, appear in Fig. 13. Lower JJA precipitation totals (Pauling et al., 2006) tended to concentrate towards the south-eastern part of central Europe (eastern Bohemia, Moravia, southern Poland, eastern Austria, Slovakia, and Hungary). While in western central Europe negative differences with respect to the reference period were much smaller, in the northern part of Poland this decade was identified as rather wet (Fig. 13a). Turning to JJA scPDSI, according to OWDA (Cook et al., 2015) spatial patterns in these terms contrast quite strongly with precipitation. Drier patterns with respect to the reference period were reconstructed for much of Germany (northwest, south-west, east), the Swiss Plateau, and Bohemia. Much wetter conditions were reconstructed for Austria, the greater part of Poland, Slovakia, and Hungary (Fig. 13b). Decadal central European fields of the two hydroclimatic characteristics show only very weak parallels, with the Pearson correlation coefficient at only 0.08 , which is thus statistically insignificant. Because PDSI depends not only on precipitation but also on temperatures, Fig. 13c shows anomalies of mean summer temperatures compared to the same reference. Although this decade was $0.8^{\circ} \mathrm{C}$ warmer than the 1961-1990 period, the degree of warming varied over central Europe. Germany, together with western Bohemia and a smaller south-to-north belt over Hungary, Slovakia, and Poland, were notably warmer. The smallest positive temperature difference extended from northern Italy to Austria, and much of Poland was also characterized by less marked differences.

Comparing the above three variables (precipitation, scPDSI, and temperature) with deviations in SLP over central Europe (Fig. 14), a clear significant negative correlation in precipitation and a significant positive correlation for air temperature are evident. Overall, the positive correlation between SLP and scPDSI is distinctly weaker, especially during the years 1531 and 1536 . This is partly due to the fact that, although drought is closely related to both precipitation and temperature, it also depends strongly upon their temporal distribution and the persistency of the periods with low precipitation and high temperatures.

Based on summer drought indices (SPI, SPEI, Z-index) for the Czech Republic (Brázdil et al., 2016a), calculated from documentary-based temperature and precipitation reconstructions for 1501-2015, JJA in the 1531-1540 decade was the driest in the past 510 years (Fig. 15a). Drought patterns in 1721-1730 nearly matched those of this decade. A similar pattern holds for gridded JJA precipitation totals in central Europe (the $45-55^{\circ} \mathrm{N}, 5-25^{\circ} \mathrm{E}$ window), reconstructed by Pauling et al. (2006) for the 1501-2000 period, followed by the 1701-1710 decade (Fig. 15b).

The uniqueness of the 1531-1540 decade is weakened when decadal characteristics in the 1501-2012 period for the same window are calculated from OWDA (Cook et al., 2015). The 1531-1540 decade, in terms of scPDSI for JJA, emerges as the ninth driest, while JJA DAI is the eighth at a threshold of -1 (Fig. 15c, d). This is probably related to the fact that summer hydroclimatic patterns are only one factor among others influencing tree growth. Moreover, the OWDA, as a spatial reconstruction, is calculated from numerous tree ring width series and is more spatially heterogeneous (see Fig. 13b). Thus, if we compare series of the Czech drought indices with the mean OWDA series over a relatively large window $\left(45-55^{\circ} \mathrm{N}, 5-25^{\circ} \mathrm{E}\right)$, OWDA seems to be rather smoothed (compare dry Bohemia and eastern Germany with wetter south-eastern Poland and Austria in Fig. 13b).

\subsection{Impacts of the 1531-1540 summers and societal responses to them}

The documentary sources for central Europe in 1531-1540 are of particular value for their reports of the impacts of weather patterns on the beginning, duration, and quantity of harvests, particularly those of grain and grapes. Certain records even enable the tracking of continuous series of harvest beginnings for the Czech Lands, Austria, and Switzerland (Fig. 16a). In general, it may be anticipated that preceding warmer and drier patterns contribute to earlier harvest dates and vice versa. Czech and Swiss series of grape harvest dates (Fig. 16b) reflect this scheme very well, clearly ex- 

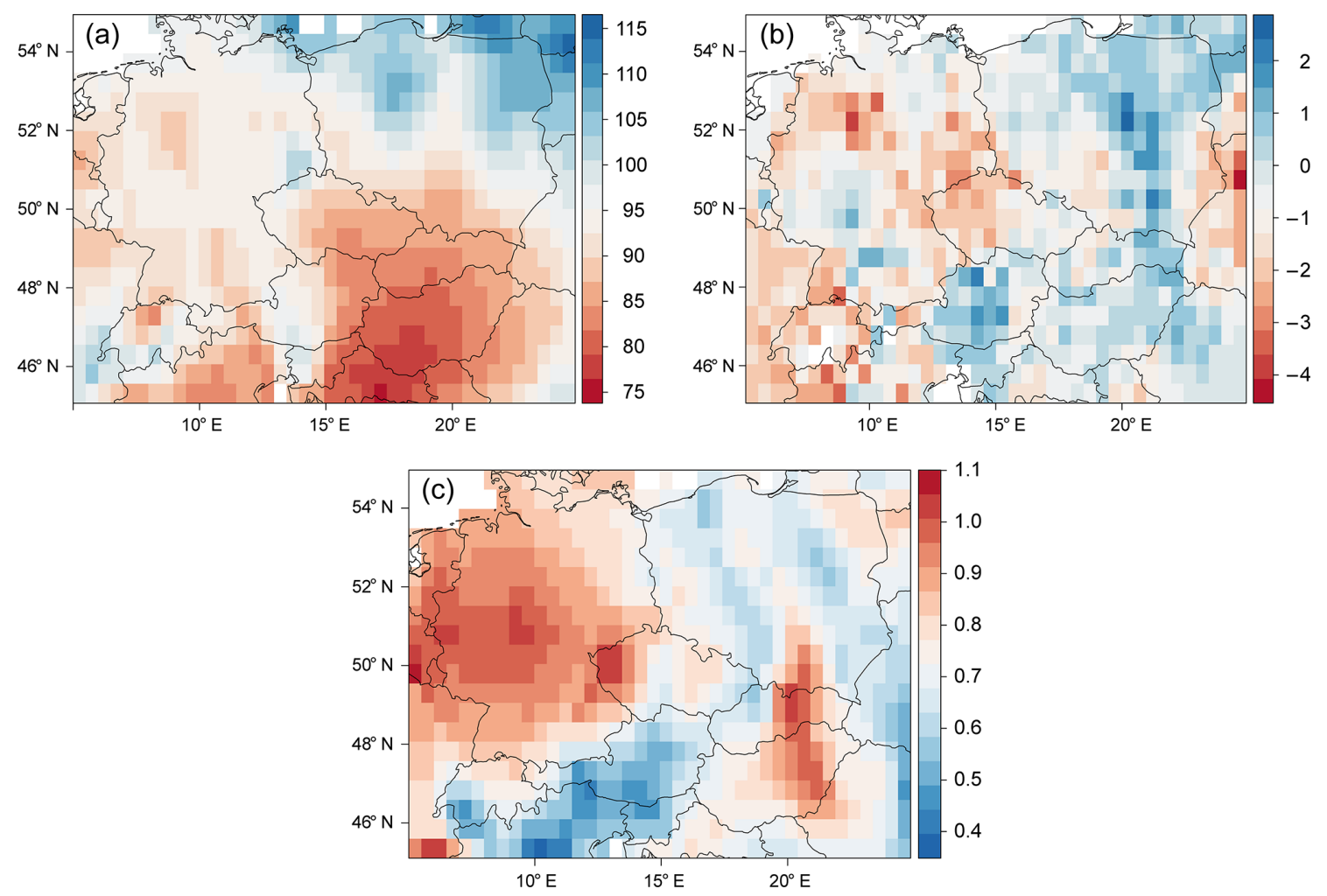

Figure 13. (a) Mean 1531-1540 JJA precipitation totals expressed as percentages of the 1961-1990 mean (Pauling et al., 2006), (b) mean 1531-1540 JJA scPDSI according to OWDA (Cook et al., 2015) expressed as deviations from the 1961-1990 mean, and (c) mean 15311540 JJA temperatures according to Luterbacher et al. (2004) expressed as deviations $\left({ }^{\circ} \mathrm{C}\right)$ from the 1961-1990 mean in the central European region.

(a)

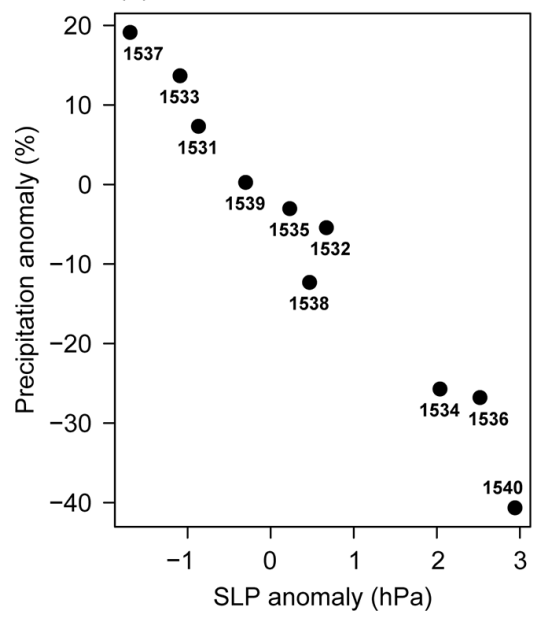

(b)

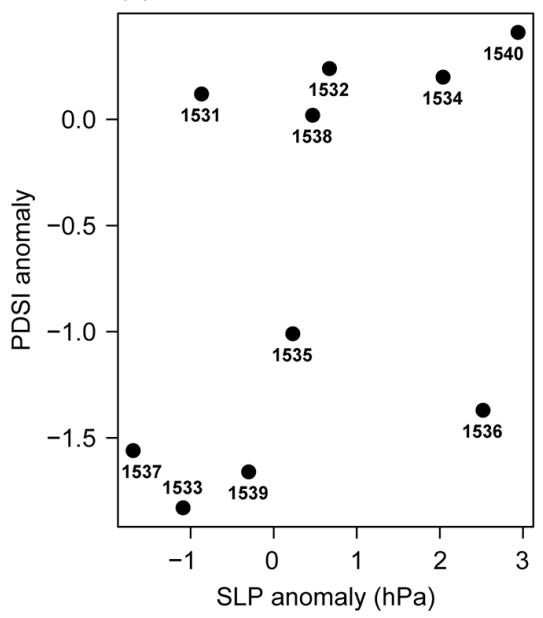

(c)

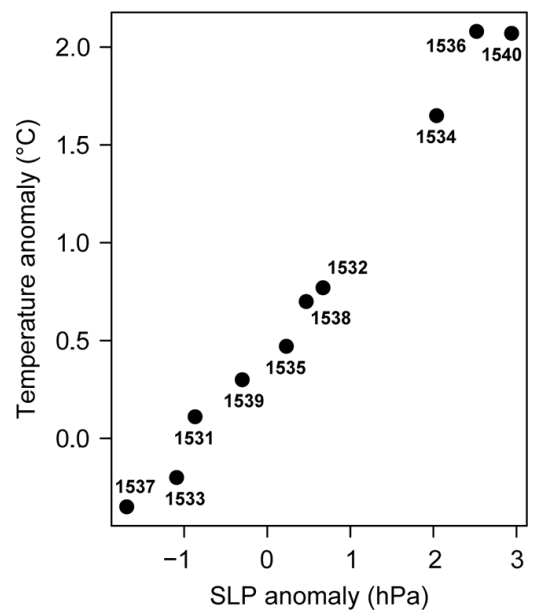

Figure 14. Relationship between mean SLP anomalies (Luterbacher et al., 2002b) and mean precipitation (a), PDSI (b), and temperature (c) anomalies for the individual summers of 1531-1540 in central Europe (the area demarcated by $45-55^{\circ} \mathrm{N}$ and $5-25^{\circ} \mathrm{E}$ ). Data sources are as follows: (a) Pauling et al. (2006), (b) Cook et al. (2015), and (c) Luterbacher et al. (2004). 
(a)
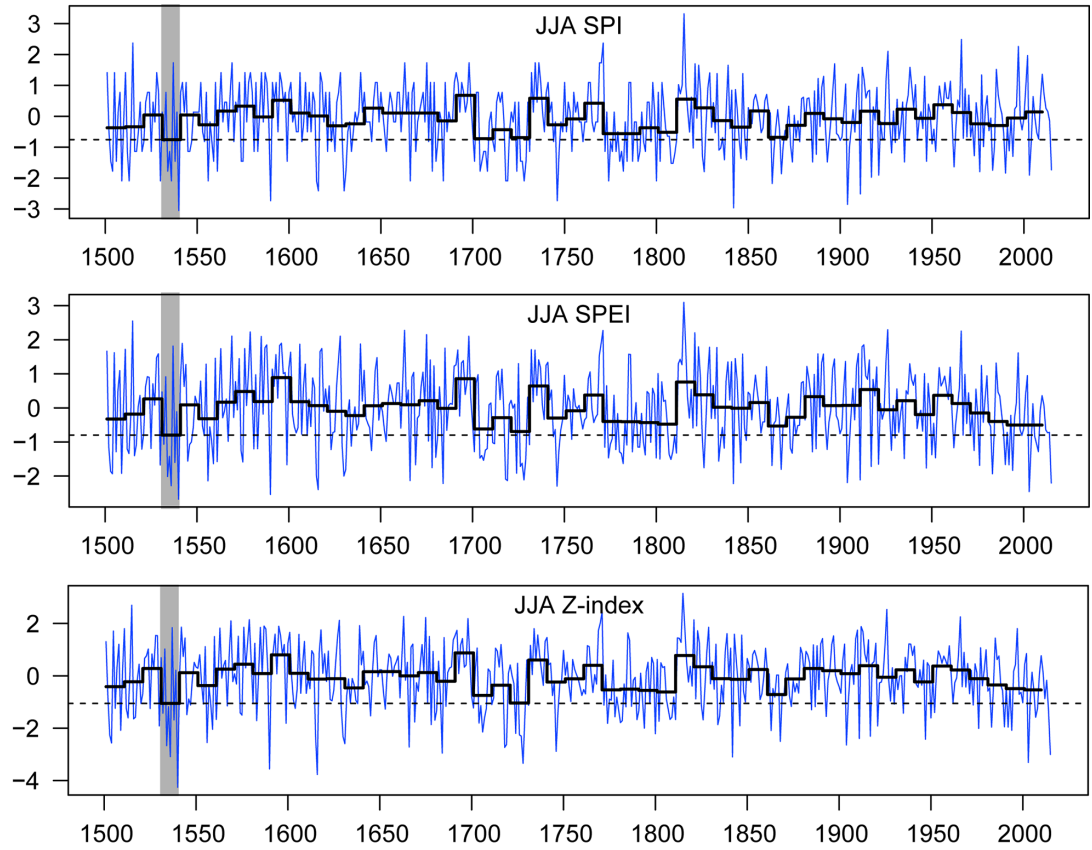

(b) 5000

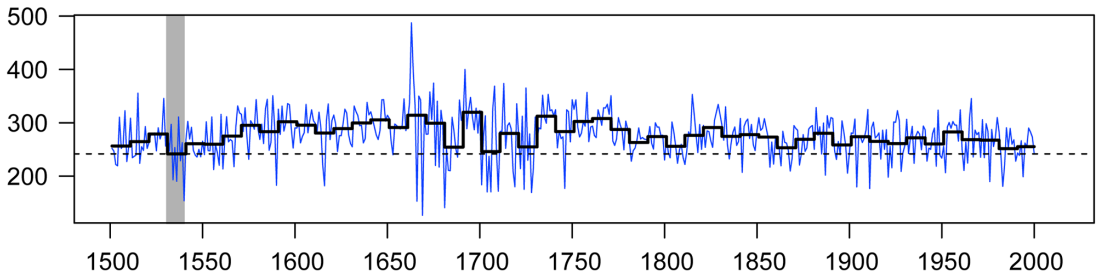

(c)

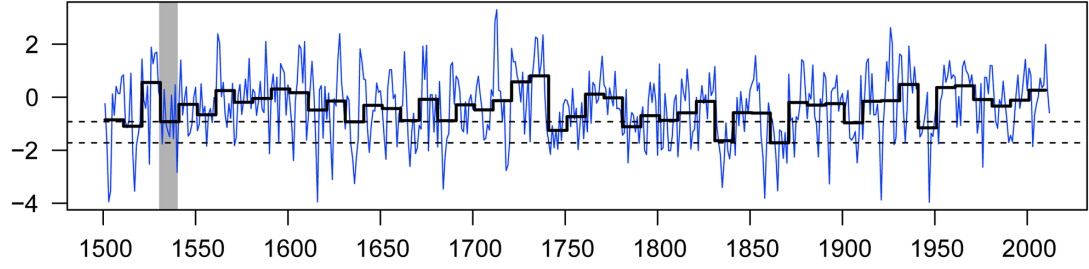

(d)

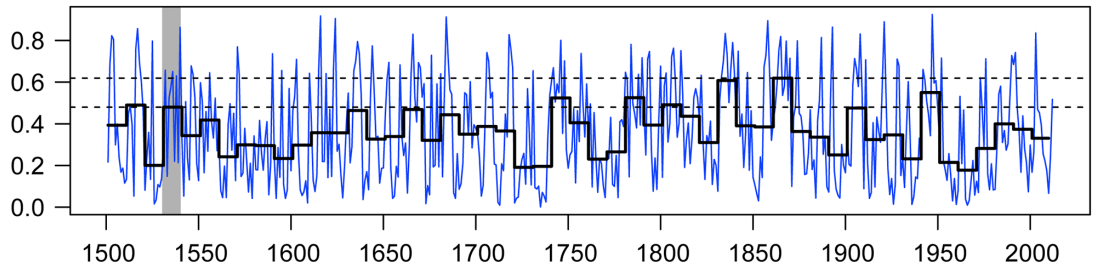

Figure 15. Decadal fluctuations in hydroclimatic characteristics: (a) JJA SPI, JJA SPEI, and JJA Z-index for the Czech Republic, 1501-2015

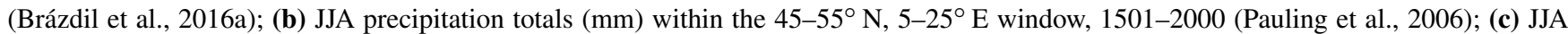
scPDSI of the $45-55^{\circ} \mathrm{N}, 5-25^{\circ} \mathrm{E}$ window, 1501-2012, according to OWDA (Cook et al., 2015); (d) JJA DAI (threshold -1) of the 45$55^{\circ} \mathrm{N}, 5-25^{\circ} \mathrm{E}$ window, 1501-2012, according to OWDA (http://drought.memphis.edu/OWDA/Default.aspx). The grey band indicates the 1531-1540 period.

pressed in the early starts for harvesting in 1540 . On the other hand, the Vienna hospital accounts relating to the grape harvest express, in comparison, a lower inter-annual variability and only partial agreement. Similar tendencies are also apparent for the grain harvest in Dobroměrice in north-western Bohemia (Brázdil and Kotyza, 2000) and for the winter rye harvest in northern Switzerland and south-western Germany (Wetter and Pfister, 2011), except for relatively long delays in harvest dates, particularly in 1536 and to a lesser degree 1537 (Fig. 16a). The Vienna series, with smoothed fluctuations, agrees in part with anticipated trends; more differences 
appear in series of the winter wheat harvest days in the Czech Lands (Možný et al., 2012).

Weather patterns for summers, together with their previous winters and springs, were reflected in good or bad yields of basic crops, influencing food sources in ways that could result in rising prices and the onset of starvation and even famine. For example, Michael Steinberg (Schönborn, 1878) published the prices of wheat and rye in his chronicle for Silesia, 1532-1541, unfortunately without further information. Wheat was the most expensive in the wet, cold year of 1533 with prices at 21-28 Groschen (so-called white Gr., equal to 31.5-42 Gr.), in 1534 (18-24 white Gr., equal to 27$36 \mathrm{Gr}$ ), and in 1538 (16-24 Gr., equal to $24-36 \mathrm{Gr}$.). Rye also commanded its highest price there (20-25 Gr.) in 1533 , although he reported $25 \mathrm{Gr}$. for rye in 1534 and 1539. Similarly, Nikolaus Pol (Büsching, 1819) noted a peak in prices in Wrocław for 1533: 25-26 Gr. for wheat and 22-24 Gr. for rye. However, the highest prices of all occurred in 1540: $26 \mathrm{Gr}$. for both wheat and rye. Steinberg in Silesia noted only $16-23 \mathrm{Gr}$. for wheat in 1540 , with no information for rye (Schönborn, 1878).

Severe shortages and very high prices for cereals were reported for 1535 in Transylvania (Schuller, 1848; VereinsAusschuß, 1851). According to Album Oltardianum, an early 17 th century chronicle, and also Wolfgang Bethlen, a history writer at around the same time, Transylvania suffered from famine in that year (Bethlen, 1782; Trauschenfels, 1860). So great was the hunger that people of both sexes and all ages lost their minds, walking around almost naked and consuming "unclean things". Bethlen also mentioned cannibalism. Thousands of people starved to death. Corpses could be encountered on the streets, their mouths full of grass (Bethlen, 1782). In Făgăraş, desperate poor people turned to eating dead dogs and cats (Trauschenfels, 1860). A century later, the history writers Wolfgang Bethlen and Matthias Miles considered this 3-year period of hunger in historical Hungary, especially severe in its northern parts (today's Slovakia) and Transylvania, almost equal to the greatest known famine of the 16th-17th centuries, which occurred in 1603 (Bethlen, 1782; Armbruster, 1984). Food availability and prices could be also negatively influenced by plague, as was reported, for example, in 1531 in Hungary (Vereins-Ausschuß, 1851), or by other epidemic diseases, as cited for the same year in Swiss Winterthur (AS10).

Warm, dry summers gave rise to particular problems in central Europe. When streams and rivers fell or dried out, it became difficult or impossible to grind grain in regions that relied upon water mills. For example, the dry summer of 1536 forced the Erfurt municipality to consider the creation of a Rossmühle, a mill powered by horses (von Falckenstein, 1738). Watering cattle was also very difficult, a problem specifically mentioned in relation to the droughts of 1536 in Germany (Ginschopff, 1631) and 1540 in Silesia (Büsching, 1819). However, it should also be pointed out that people had no problems with access to water in the towns sit- uated near big rivers such as the River Vistula in Poland, even in times of extreme drought. On the other hand, wet summers were sometimes accompanied by floods that could cause material damage and flooding of agricultural land, or even loss of human lives, as was apparent in 1533 in Bohemia (Zilynskyj, 1984), Poland (including Silesia) (Büsching, 1819; Maurer, 1878), Switzerland (Fouquet, 1999), and Transylvania (Vereins-Ausschuß, 1851; Gross and Seraphin, 1903b) and again in 1537 in Bohemia (Zilynskyj, 1984), Silesia (Büsching, 1819), and Germany (e.g., Spangenberg, 1572; Lappenberg, 1861; Freihern von Oefele, 1878; Koch, 1937).

In times of extended and severe droughts, the number of fires in towns and forests rose. For example, forest fires were reported in 1532 in Silesia (Büsching, 1819), in 1536 and 1538 in Bohemia (AS7; Gradl, 1884; Kolár, 1987), and in 1540 in the Brandenburg area (Riedel, 1862), Carinthia (Rohr, 2007), Silesia (Büsching, 1819), Bohemia, Silesia and Lusatia (Gomolcke, 1737), and Transylvania (Schuller, 1848).

\section{Discussion}

\subsection{The summers of 1531-1540 in European context}

The character of the summer weather described in Sect. 4.1 and 4.3 may be confirmed by other central European studies. For example, Limanówka (2001) used qualitative daily weather records from ephemerides in Kraków (Poland), covering the first half of the 16th century, to classify temperature-precipitation patterns. She interpreted the summers of 1531-1540 as follows: 1531 , warm, mean precipitation (37 precipitation days); 1532-1534, no data; 1535, cool, mean precipitation (42); 1536, moderate, dry (35); 1537, moderate, humid (47); 1538, warm, dry (39); 1539, moderate, humid (42); and 1540, very hot, extremely dry (13).

A range of documentary evidence has been used to interpret the summer patterns of 1531-1540 in Germany (Glaser, 2008) and in Switzerland (Pfister, 1988, 1999). A very warm, dry summer in 1532 (particularly August) was recorded in southern and eastern Germany (Glaser, 2008), while a warm June and August were derived for Switzerland (Pfister, 1988). Pfister (1988) interprets a wet summer for 1533 in Switzerland, while Glaser (2008) gives a cooler and wetter summer in Germany. A warm, dry summer for 1534 follows from the interpretations of documentary data for both Germany (Glaser, 2008) and Switzerland (Pfister, 1988). Glaser's analysis (2008) for 1535 in Germany provides spatially different intensities of heat in the summer, which became moist towards the end. In Switzerland (data missing for July), the months of June and August were interpreted as average, and June was further interpreted as wet (Pfister, 1988). The analysis for 1536 in Germany gives a mild, dry spring, a very warm and very dry summer, and a warm, very dry autumn (Glaser, 2008). For Switzerland, Pfister (1988) mentions warm months from May to November, and dry- 

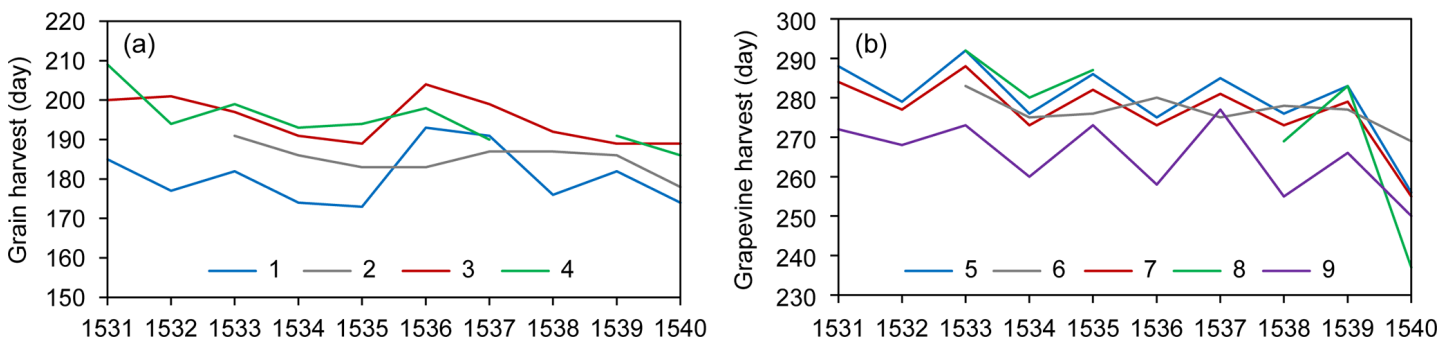

Figure 16. Harvest starting days, expressed as days after 1 January, for selected locations and regions in central Europe and France in 1531-1540: (a) grain (1 - Dobroměřice: Brázdil and Kotyza, 2000; 2 - Vienna: AS15; 3 - winter wheat - Czech Lands: Možný et al., 2012; 4 - winter rye - northern Switzerland and south-western Germany: Wetter and Pfister, 2011); (b) grapes (5 - the Louny region: Brázdil et al., 2019d; 6 - Vienna: AS15; 7 - Bohemian viticulture region: Možný et al., 2016; 8 - Switzerland: Meier et al., 2007; 9 - Beaune, France: Labbé et al., 2019).

ness from July to October (July-September were classified as anomalously warm-dry - Pfister, 1999). Glaser's analysis (2008) for 1537 gives a cold and very wet summer for Germany, particularly in June. While the data for summer 1538 in Switzerland are incomplete (Pfister, 1988), Glaser (2008) interprets warm and dry summer for Germany. Glaser (2008) speaks of summer 1539 as wet, although with less rain in western and eastern Germany. Pfister (1988) mentions a warm June and August for Switzerland, but the data for July are missing. The extraordinary extremity of the year 1540 is recorded by Pfister (1988) for Switzerland, who mentions a sequence of warm months from April to December and dry ones from February to October. Similar reports of warm and dry patterns also come from Germany (Glaser, 2008).

Based on the quantitative precipitation reconstruction from documentary sources for the Czech Lands by Dobrovolný et al. (2015), summer precipitation totals for the 1530s were lower than in the 1961-1990 reference period and also compared with the preceding (1520s) and subsequent (1540s) decades. Further, low precipitation in the 1530s in central Europe was confirmed in four proxy reconstructions based on tree ring widths, although they refer to slightly different seasons (see Fig. 9 in Dobrovolný et al., 2018, for further details).

High temperatures in addition to low precipitation could also have contributed significantly to droughts. For example, summer temperatures for central Europe reconstructed from documentary sources (Dobrovolný et al., 2010) indicate that the $1531-1540$ decade was $0.9{ }^{\circ} \mathrm{C}$ warmer than the $1961-$ 1990 reference period. The former decade was significantly warmer (at a significance level of 0.05 ) than the previous (1521-1530) and subsequent (1541-1550) decades. Moreover, a majority of the 15 various proxy reconstructions from central Europe performed by Brázdil et al. (2013b) have confirmed the exceptionally warm character of the 1530s.

It follows from Figs. 1-10 that summer weather patterns in western Europe were similar to those in central Europe. In particular, the summers of 1534, 1536, 1538, and 1540 were not only dry in central Europe but the area affected by drought also extended over the greater part of western Europe. Pribyl and Cornes (2020) mentioned repeated warm and dry episodes in the 1530s and a drought in 1540 in England. In the Netherlands, Alsace, and France, summer 1532 was sunny and very dry with a good grape harvest (Bournon, 1895; Buisman, 1998). Summer 1533 in the Netherlands was wet with prolific rain in June, July, and August. As a result, the water in several rivers was high, leading to flooding and burst dikes in the Nijmegen, Doesburg, and Den Bosch areas (Buisman, 1998). Summer 1534 in the Paris district was hot and very dry from April until autumn, and the grain harvest was good (Bournon, 1895). On the other hand, summer 1535 was rainy and quite cold in the Paris area and Alsace (Buisman, 1998). Summer 1538 was dry in the Netherlands (ibid.). In the Netherlands and in Alsace, summer 1539 was quite warm with some dry spells, but there were periods of rain. The hay and grape harvests were good in both areas (ibid.). Dry and warm patterns for 1540 in western Europe have been confirmed by Wetter et al. (2014). In the Netherlands, this summer was extraordinarily hot. People had not experienced anything similar for hundreds of years. Fountains dried up and even large rivers such as the Rhine, Maas, Leie, and Scheldt ran very low. There was almost no rain at all. Wildfires and town fires broke out in several places. Harvests were very early, and while damage to vegetation was reported in some places, in others the harvests were abundant (Buisman, 1998).

Only sparse information concerning drought episodes in the summers of 1531-1540 is available from eastern Europe. In contrast to central and western Europe in 1533, severe drought was reported in Russian annals for the eastern European plain. In its central part (the Moscow area) the annalist wrote the following (Shmakin et al., 2013, p. 53):

No rain from June to September but drought [zasucha] and heavy fog [generated] by hot smoke from burnt-out forests and dried-up peat bogs. The sun at three [in the afternoon] was red and it was impossible to see by it. 
The situation was similar in the northern part of the plain (the Novgorod area): extended spell without rain, dried-up bodies of water, forest fires, and smoke (ibid.).

\subsection{Impacts and societal responses to the summers of 1531-1540}

Partial comparisons may be drawn between the impacts of drought and society's responses to it in central Europe through further similar documentation. For example, in the Paris region (Bournon, 1895), after a cold and rainy May 1531 , the market price of grain was very high the following summer. A very good vintage was reported in 1532, with an abundance of wine at market. Hot, dry weather also occurred in this area in the months of May, June, and July 1534, when a lack of hay and oats was mentioned. However, it appears that the wheat harvest was at least sufficient. In Burgundy and Alsace, the grape, fruit, and grain harvests were early and good in 1536 (Buisman, 1998). French grape harvest days at Beaune (Labbé et al., 2019) correlate closely with the general character of the summers of 1531-1540, as well as with that of other central European series (Fig. 16b).

Turning to the consequences of dry weather, central European documentary sources often describe problems with the availability of water and activities related to its levels. For example, during the extremely hot, dry summer of 1540 in the Netherlands, the water levels in rivers were so low that people could cross substantial rivers such as the Lys, the Scheldt, the Meuse, and the Rhine with "dry feet" (Descamps, 1852).

Soon after the 1531-1540 decade examined herein, in 1542, locusts invaded central Europe (Brázdil et al., 2014). However, Count Lestár Gyulaffy, a Transylvanian diplomat, mentioned in his historical annals, completed in 1605, that the infamous central European locust invasion of the early to mid-1540s had already begun in 1539 in Transylvania. Although he was not an immediately contemporaneous author (he was born in 1557), his dating of such an early outbreak is worthy of mention, as his work otherwise contains a correct historical chronology of political and other events (Szilágyi, 1893).

As shown by described individual impacts in Sect. 4.1, it follows that there were no indications of multi-country or multi-year severe impacts. This could be related to several circumstances. Because of the differences in sensitivity of the various agricultural crops to temperatures and precipitation in different stages of their development, their yields were significantly influenced by the weather not just in summer but also in other seasons, particularly spring, but to a lesser extent autumn and winter as well. Further, dry years with possible severe impacts were broken by years with normal or wetter patterns, it is then that there was no a longer concentration of worse weather patterns strongly influencing agricultural production over the long term in a negative way. Moreover, great spatial precipitation variability meant that the all of central Europe was not affected in the same way, and to some extent trade could buffer the potential negative effects. Moreover, the relatively stable socio-political situation without wars and extensive plague epidemics allowed administrations to settle regionally limited shortages, despite the fact that some regions such as the Carpathian Basin generally suffered from Turkish and German attacks, taxationrelated economic issues, and internal political controversies (e.g. Perjés, 1989), the circumstances of which also make it more difficult to single out the problems primarily caused by unfavourable weather conditions. In this context we have to take in account that attention to recording of weather anomalies was sometimes of secondary importance compared to reporting other societal events, i.e. some impacts could remain unnoticed.

\section{Conclusion}

The results of this analysis of summer hydroclimatic patterns during the 1531-1540 decade in central Europe may be summarized as follows:

i. Reconstructions based on documentary data indicate that the summers of 1531-1540 were the driest summer decade in central Europe of the past 5 centuries, i.e. following $1501 \mathrm{CE}$. Dry patterns were expressed at their clearest in 1532, 1534-1536, 1538, and particularly in 1540, which was extremely dry. Reconstructions based on tree ring widths tend to attribute the JJA scPDSI of 1531-1540 to the end of the first 10 driest summers.

ii. Drier summers in central Europe correspond with pressure increases over Fennoscandia and central Europe and to statistically significant pressure decreases in the central part of the Atlantic Ocean and south-western Europe. Wetter summers correspond with pressure decreases extending from the British Isles to central Europe.

iii. The impacts of summer droughts within the 1531-1540 period were reflected in familiar manifestations, such as bad harvests of certain crops, reduction or complete lack of water sources, and frequent fires in towns and forests, contrasting with floods and all their negative effects in wetter summers. However, there are no indications that the more severe impacts were of a multicountry or multi-year nature.

iv. Despite the fact that precipitation totals and PDSI represent different hydroclimatic characteristics, the multi-proxy precipitation reconstruction by Pauling et al. (2006) and scPDSI tree ring width reconstruction by Cook et al. (2015) indicate only little agreement in the spatial distribution of drier and wetter patterns over (central) Europe in the summers of 1531-1540.

v. The current study demonstrates the high potential of documentary data in the detailed analysis of weather 
patterns of past summers in Europe. These occurred in times of only natural processes. This is very relevant to the evaluation of recent and future droughts arising out of the effects of both natural and anthropogenic forcings.

Data availability. The series of hydroclimatic, pressure, and temperature reconstructions were obtained from following databases: http://drought.memphis.edu/OWDA/Default.aspx (Cook et al., 2015) for scPDSI; https://www.ncdc.noaa.gov/paleo-search/study/ 6342 (Pauling et al., 2020) for precipitation; https://www.ncdc. noaa.gov/paleo-search/study/6366 (Luterbacher et al., 2020a) for sea level pressure; and https://www.ncdc.noaa.gov/paleo-search/ study/6288 (Luterbacher et al., 2020b) for air temperature. Sources of weather and related information were extracted from quoted archival sources and references.

Supplement. The supplement related to this article is available online at: https://doi.org/10.5194/cp-16-2125-2020-supplement.

Author contributions. RB designed and wrote the paper with contributions from all co-authors. PD analysed spatial distribution and did analyses of precipitation, PDSI, SLP, and temperature on a European and central European scale. The following colleagues contributed with documentary data: MB for Germany, CC for Switzerland and western Europe, AK for former Hungarian lands and Transylvania, OK for the Czech Lands, and PO for Poland. LK worked with Tambora and EuroClimhist databases and finalized the figures. All authors have read and commented on the latest version of the paper.

Competing interests. The authors declare that they have no conflict of interest.

Special issue statement. This article is part of the special issue "Droughts over centuries: what can documentary evidence tell us about drought variability, severity and human responses?". It is not associated with a conference.

Acknowledgements. Rudolf Brázdil, Petr Dobrovolný, and Ladislava Rezníčková were supported by the Ministry of Education, Youth and Sports of the Czech Republic for the SustES - Adaptation strategies for sustainable ecosystem services and food security under adverse environmental conditions (project no. CZ.02.1.01/0.0/0.0/16_019/0000797). Martin Bauch was supported by a Freigeist Fellowship from the Volkswagen Foundation. Andrea Kiss acknowledges financial support from the Austrian Science Fund (project no. I 3174). Piotr Oliński was supported by the National Science Centre, Poland (grant no. DEC2013/11/b/HS3/01458), as part of the programme "Climatic conditions in South Baltic Areas in the second half of the 15th and 16th centuries and their consequences for social, economic and cul- tural life". This study was undertaken by CRIAS, a working group of the Past Global Changes (PAGES) project, which in turn received support from the Swiss Academy of Sciences and the Chinese Academy of Sciences. The authors also acknowledge Climate Explorer (https://climexp.knmi.nl, last access: 22 May 2020), which was used to plot the maps that appear as Figs. 1-10. Tony Long (Dalmellington) helped to improve the quality of the English.

Financial support. This research has been supported by the Ministry of Education, Youth and Sports of the Czech Republic (grant no. CZ.02.1.01/0.0/0.0/16_019/0000797), the Volkswagen Foundation, the Austrian Science Fund (project no. I 3174), and the National Science Centre, Poland (grant no. DEC2013/11/b/HS3/01458).

Review statement. This paper was edited by Stefan Grab and reviewed by two anonymous referees.

\section{Archival sources}

- [AS1] Archiv hlavneho mesta SR Bratislavy, Magistrát mesta Bratislavy (AMB-A/XXIV.1): Komarna kniha/Kammerbuch: K1-56 (1434-1500).

- [AS2] Győr-Moson-Sopron Megye Soproni Levéltára IV. 1003. Acta decimalia.

- [AS3] Moravská zemská knihovna Brno, sign. 25363 : Kniha Duchovní o velikých skutcích Pána Boha všemohoucího: Rozličnými hystoriemi starými i novými ozdobená. V níž se obsahuje vysvětlení: Mohouli Čarodějníci a Čarodějnice sami od sebe Povětří, Kroupy, Bouře, Hromobití vzbuditi a vyvésti. Z Písem Svatých, Učitelův Křestanských i Pohanských sepsaná a nyní v nově vydaná. Od kněze Jana Štelcara Želetavského z Želetavy, toho času Faráře v Městečku Mnichovicích. Létha Páně: MDLXXXVIII.

- [AS4] Moravská zemská knihovna Brno, sign. L.VIII.187: Chronica der kayserlichen freyen Bergstadt Sanct Jo[a]chimsthal der zuvor die Conradsgrün genent war. Anhang in Johann Mathesius, Sarepta oder Bergpostill. Sampt der Jo[a]chimsztalischen kurzen Chroniken. Psalm. CXLVIII. Berg und Thallober den HLRRN. Nürnberg, MDLII.

- [AS5] Moravský zemský archiv Brno, fond G 21 Sbírka starých tisků, inv. č. 526, sign. III/160: Rerum Boemicarum Ephemeris sive Kalendarium historicum. Ex reconditis veterum annalium monumentis crutum. Authore M. Procopio Lupacio [de] Hlavaczov aeo, Pragensi. Opus nunc primum in lucem editum, una cum coronide ac locuplere personarum et rerum memorabilium indice. In idem kalendarium. Eruta dum patriae monumenta Lupacius edit, et bonus est civis, doctus 
et historicus. Suscitat, amplificat, manifestat, promovet, ornat, maiores, patriam, tempora, gesta, duces. M. Bern. Sturmii. Pragae, Anno M.D.LXXXIIII.

- [AS6] Národní knihovna České republiky Praha, sign. XVII. B. 14: Urbář kláštera doksanského založený r. 1522 s přepisy listin právních zboží téhož kláštera z 16. století (do r. 1588) a se zprávami kronikářskými z let 1453-1531.

- [AS7] Regionální muzeum Litoměřice, inv. č. SV 14142: Kalendár Historický. To jest krátké poznamenání všech dnuov jednoho každého měsíce přes celý rok. K nim přidány jsou některé paměti hodné Historiae o rozličných příhodách a proměnách, jak národuov jiných a zemí v Světě, tak také a obzvláštně národu i Království Českého z hodnověrných Kronik. S pilnosti sebráno, vytištěno a vydáno prací a nákladem M. Daniele Adama z Veleslavína. Vytlačeno v Starém Městě Pražském. Leta posledního věku: MDXC.

- [AS8] Sächsische Landesbibliothek - Staats- und Universitätsbibliothek Dresden, sign. VW/93/135: Georgii Fabricii Chemnicensis Rerum Misnicarum libri VII. Electorum Saxoniae lib. I. Marchionum Misnensium lib. I. Annalium urbis Misnae libri III. Siffridi Misnensis presbyteri Epitomes lib. II. Omnia nunc recens edita. Lipsiae. Curante Ernesto Voegelino. Cum provilegio.

- [AS9] Stadtarchiv Mühlhausen, sign. 61: Anonymus, Die Mühlhäusischen Alterthümer in einer Chronica vorgestellet zum Nützlichen Gebrauch vor die Nachkommen aus vielen Alten Schrifften und Chronicken zusammengetragen Im Jahr Christi 1800, Zweyther Theil. Illustrierte Sammelhandschrift aus dem Besitz von Amalia Mohts, geb. Becke.

- [AS10] Stadtbibliothek Winterthur: Goldschmid, J. J.: Erzellung seltsammer Natur-Geschichten ungwohnten Jahrgängen: theuren und wohlfeilen Zeiten, Sterbensläuffen und anderen derglichen Sachen so sich bey uns in der Statt Winterthur zuogetragen haben.

- [AS11] Státní okresní archiv Litoměřice, fond Archiv města Litoměřice, sign. IV B 1a: Kniha pamětní litoměřických městských písařo̊ 1570-1607.

- [AS12] Státní okresní archiv Litoměřice, fond Archiv města Litoměřice, st. sign. 12: Letopisecké záznamy v litoměřickém právním rukopise ze 14. stol. označený nově "Das Magdeburger Recht".

- [AS13] Státní okresní archiv Louny, fond Archiv města Louny - kroniky, sign. Ch 1: Chronica civitatis Launensis in Boemia auctore Paulo Mikssowicz servo consulari.
- [AS14] Státní okresní archiv Louny, fond Archiv města Louny, sign. I E 10: Iste liber pro hospitali et curia allodiali deputatus inicium sui cepit post exustam hanc urbem etc.

- [AS15] Wiener Stadt- und Landesarchiv, MA 8. 1.7.1.1. B 11 - Spitalmeisteramtsrechnung 1531, 1533-1540.

\section{References}

Aldenberger, J.: Fewer- Wasser- vnd Wein Spiegel: das ist, kurtze vnd ordentliche verzeichnüss der Fewersbrünsten vnd Wasserfluten so sich in sechstehalb tausend Jahren, von der Welt Anfang biss vff gegenwertige Zeit, in Städten vnd Dörffen des Deutschlandes [...], Typis Grosianis, Leipzig, 1615.

Armbruster, A. (Ed.): Miles, M., Siebenbürgischer Würg-Engel oder Chronicalischer Anhang des 15. Seculi nach Christi Geburth aller theils in Siebenbürgen theils Ungern und sonst Siebenbürgen angräntzenden Ländern fürgelauffener Geschichten, Böhlau Verlag, Köln, Wien, 1984.

Arnold, G.: Chronicon Annaebergense Continuatum, Hasper, Annaberg, 1812.

Baechtold, C. A. (Ed.): Hans Oswald Huber's Schaffhauser Chronik, Beiträge zur vaterländischen Geschichte, 8, 83-146, 1906.

Baechtold, J. (Ed.): Hans Salat, ein schweizerischer Chronist und Dichter aus der ersten Hälfte des XVI. Jahrhunderts. Sein Leben und seine Schriften, Bahnmaier's, Basel, 25-69, 1876.

Bal, J., Förser, J., and Kauffmann, A.: Hain Gáspár lőcsei krónikája (The Levoča chronicle of Gaspar Hain), Reiss Józs. T. Könyvnyomó Intézete, Lốcse, 1910-1913.

Barabás, S. (Ed.): Székely krónika (The Secler Cronicle), Történelmi Tár 1880, M. Tud. Akadémia, Budapest, 1880.

Bauch, M., Labbé, T., Engel, A., and Seifert, P.: A Prequel to the Dantean Anomaly: The Water Seesaw and Droughts of 13021307 in Europe, Clim. Past Discuss., https://doi.org/10.5194/cp2020-34, in review, 2020.

Bernoulli, A. (Ed.): Die Chronik Konrad Schnitts, 1518-1533, sammt Forsetzung bis 1537, in: Basler Chroniken, Sechster Band, S. Hirzel, Leipzig, 86-164, 1902.

Bethlen, W. de: Historia de rebus Transsylvanicis, Editio secunda, Tomus primus, Martini Hochmeister, Cibinii, 1782.

Bhalme, H. N. and Mooley, D. A.: Large-scale droughts/floods and monsoon circulation, Mon. Weather Rev., 108, 1197-1211, https://doi.org/10.1175/15200493(1980)108<1197:LSDAMC>2.0.CO;2, 1980.

Biermann, G.: Geschichte des Herzogsthums Teschen, In Commission Verlage bei Karl Prochaska, Teschen, 1863.

Blumer, J. J.: Die Chronik von Valentin Tschudi, Archiv für Schweizerische Geschichte, 9, 335-447, 1853.

Bournon, F. (Ed.): Chronique Parisienne de Pierre Driart, Chambrier de Saint-Victor, 1522-1535, Mémoires de la Société de l'Histoire de Paris et l'Ile de France, 22, 67-178, 1895.

Brázdil, R. and Kotyza, O.: History of Weather and Climate in the Czech Lands II. The earliest daily observations of the weather in the Czech Lands, Masaryk University, Brno, 1996.

Brázdil, R. and Kotyza, O.: History of Weather and Climate in the Czech Lands IV. Utilisation of economic sources for the study of 
climate fluctuation at Louny and surroundings in the fifteenthseventeenth centuries, Masaryk University, Brno, 2000.

Brázdil, R., Pfister, C., Wanner, H., von Storch, H., and Luterbacher, J.: Historical climatology in Europe - the state of the art, Climatic Change, 70, 363-430, https://doi.org/10.1007/s10584-005-5924$1,2005$.

Brázdil, R., Dobrovolný, P., Luterbacher, J., Moberg, A., Pfister, C., Wheeler, D., and Zorita, E.: European climate of the past 500 years: new challenges for historical climatology, Climatic Change, 101, 7-40, https://doi.org/10.1007/s10584-009-9783-z, 2010.

Brázdil, R., Dobrovolný, P., Trnka, M., Kotyza, O., Řezníčková, L., Valášek, H., Zahradníček, P., and Štěpánek, P.: Droughts in the Czech Lands, 1090-2012 AD, Clim. Past, 9, 1985-2002, https://doi.org/10.5194/cp-9-1985-2013, 2013a.

Brázdil, R., Kotyza, O., Dobrovolný, P., Řezníčková, L., and Valášek, H.: Climate of the Sixteenth Century in the Czech Lands, Masaryk University, Brno, 2013b.

Brázdil, R., Řezníčková, L., Valášek, H., Kiss, A., and Kotyza, O. (2014): Past locust outbreaks in the Czech Lands: do they indicate particular climatic patterns?, Theor. Appl. Climatol., 116, 343-357, https://doi.org/10.1007/s00704-013-0950-9, 2014.

Brázdil, R., Dobrovolný, P., Trnka, M., Büntgen, U., Řezníčková, L., Kotyza, O., Valášek, H., and Štěpánek, P.: Documentary and instrumental-based drought indices for the Czech Lands back to AD 1501, Clim. Res., 70, 103-117, https://doi.org/10.3354/cr01380, 2016a.

Brázdil, R., Raška, P., Trnka, M., Zahradníček, P., Valášek, H., Dobrovolný, P., Řezníčková, L., Treml, P., and Stachoň, Z.: The Central European drought of 1947: causes and consequences, with particular reference to the Czech Lands, Clim. Res., 70, 161-178, https://doi.org/10.3354/cr01387, 2016b.

Brázdil, R., Kiss, A., Luterbacher, J., Nash, D. J., and Řezníčková, L.: Documentary data and the study of past droughts: a global state of the art, Clim. Past, 14, 1915-1960, https://doi.org/10.5194/cp-14-1915-2018, 2018.

Brázdil, R., Demarée, G. R., Kiss, A., Dobrovolný, P., Chromá, K., Trnka, M., Dolák, L., Řezníčková, L., Zahradníček, P., Limanowka, D., and Jourdain, S.: The extreme drought of 1842 in Europe as described by both documentary data and instrumental measurements, Clim. Past, 15, 1861-1884, https://doi.org/10.5194/cp-15-1861-2019, 2019a.

Brázdil, R., Dobrovolný, P., Trnka, M., Řezníčková, L., Dolák, L., and Kotyza, O.: Extreme droughts and human responses to them: the Czech Lands in the pre-instrumental period, Clim. Past, 15, 1-24, https://doi.org/10.5194/cp-15-1-2019, 2019 b.

Brázdil, R., Kiss, A., Řezníčková, L., and Barriendos, M.: Droughts in historical times in Europe, as derived from documentary evidence, in: Palaeohydrology. Traces, Tracks and Trails of Extreme Events, edited by: Herget, J. and Fontana, A., Springer Nature Switzerland AG 2020, Cham, 65-96, 2019c.

Brázdil, R., Možný, M., Klír, T., Řezníčková, L., Trnka, M., Dobrovolný, P., and Kotyza, O.: Climate variability and changes in the agricultural cycle in the Czech Lands from the sixteenth century to the present, Theor. Appl. Climatol., 136, 553-573, https://doi.org/10.1007/s00704-018-2508-3, 2019d.

Buisman, J.: Duizend jaar weer, wind en water in the Lage Landen, vol. 3, 1450-1575, Uitgeverij Van Wijnen, Franeker, 1998.
Büntgen, U., Tegel, W., Career, M., Krusic, P. J., Hayes, M., and Esper, J.: Commentary to Wetter et al. (2014): Limited tree-ring evidence for a 1540 European "Megadrought", Climatic Change, 131, 183-190, https://doi.org/10.1007/s10584015-1423-1, 2015.

Büsching, J. G. (Ed.): Jahrbücher der Stadt Breslau von Nikolaus Pol, Band III, Vereins für Schlesische Geschichte und Alterthümer, Breslau, 1819.

Camenisch, C., Brázdil, R., Kiss, A., Pfister, C., Wetter, O., Rohr, C., Contino, A., and Retsö, D.: Extreme heat and drought in 1473 and their impacts in Europe in the context of the early 1470s, Reg. Environ. Change, 20, 19, https://doi.org/10.1007/s10113020-01601-0, 2020.

Chase, T. N., Wolter, K., Pielke, R. A. Sr., and Rasool, J.: Was the 2003 European summer heat wave unusual in the global context?, Geophys. Res. Lett., 33, L23709, https://doi.org/10.1029/2006GL027470, 2006.

Cook, E. R., Seager, R., Kushnir, Y., Briffa, K. R., Büntgen, U., Frank, D., Krusic, P. J., Tegel, W., van der Schrier, G., AndreuHeyles, L., Bailie, M., Baittinger, C., Bleicher, N., Bonde, N., Brown, D., Carrer, M., Cooper, R., Čufar, K., Dittmar, C., Esper, J., Griggs, C., Gunnarson, B., Günther, B., Gutierrez, E., Haneca, K., Helama, S., Herzig, F., Heussner, K.-U., Hofmann, J., Janda, P., Kontic, R., Köse, N., Kyncl, T., Levanič, T., Linderholm, H., Manning, S., Melvin, T. M., Miles, D., Neuwirth, B., Nicolussi, K., Nola, P., Panayotov, M., Popa, I., Rothe, A., Seftigen, K., Seim, A., Svarva, H., Svoboda, M., Thun, T., Timonen, M., Touchan, R., Trotsiuk, V., Trouet, V., Walder, F., Ważny, T., Wilson, R., and Zang, C.: Old World megadroughts and pluvials during the Common Era, Sci. Adv., 1, e150061, https://doi.org/10.1126/sciadv.1500561, 2015 (data available at: http://drought.memphis.edu/OWDA/Default.aspx, last access: 8 January 2020).

Curicke, R.: Der Stadt Dantzig historische Beschreibung, Joan und Gillis Janssons von Waesberge, Amsterdam, the Netherlands, Dantzig, 1688.

d'Elvert, C. (Ed.): Chronik der königlichen Stadt Iglau (14021617) von Iglauer Stadtschreiber Martin Leupold von Löwenthal, Quellen-Schriften zur Geschichte Mährens und Österr.Schlesiens, 1. Sektion: Chroniken u. dgl., Theil 1. Mährische und schlesische Chroniken, In Commission der Buchhandlung A. Nitsch, Brno, 1861.

Descamps, A. P. V. (Ed.): Annales de la Province et Comté du Hainaut, contenant les choses les plus remarquables advenues dans ceste province [...] par François Vinchant, Tome cinquième, Typographie d'Emm. Hoyois, Mons, 1852.

Diodato, N. and Bellocchi, G.: Historical perspective of drought response in central-southern Italy, Clim. Res., 49, 189-200, https://doi.org/10.3354/cr01020, 2011.

Dobrovolný, P., Moberg, A., Brázdil, R., Pfister, C., Glaser, R., Wilson, R., van Engelen, A., Limanówka, D., Kiss, A., Halíčková, M., Macková, J., Riemann, D., Luterbacher, J., and Böhm, R.: Monthly and seasonal temperature reconstructions for Central Europe derived from documentary evidence and instrumental records since AD 1500, Climatic Change, 101, 69-107, https://doi.org/10.1007/s10584-009-9724-x, 2010.

Dobrovolný, P., Brázdil, R., Trnka, M., Kotyza, O., and Valášek, H.: Precipitation reconstruction for the Czech 
Lands, AD 1501-2010, Int. J. Climatol., 35, 1-14, https://doi.org/10.1002/joc.3957, 2015.

Dobrovolný, P., Rybníček, M., Kolář, T., Brázdil, R., Trnka, M., and Büntgen, U.: May-July precipitation reconstruction from oak tree-rings for Bohemia (Czech Republic) since AD 1040, Int. J. Climatol., 38, 1910-1924, https://doi.org/10.1002/joc.5305, 2018.

Domínguez-Castro, F., Santisteban, J. I., Barriendos, M., and Mediavilla, R.: Reconstruction of drought episodes for central Spain from rogation ceremonies recorded at the Toledo Cathedral from 1506 to 1900: A methodological approach, Global Planet. Change, 63, 230-242, https://doi.org/10.1016/j.gloplacha.2008.06.002, 2008.

Dreyhaupt, J. C.: Pagus neletici et nudzici oder ausführliche diplomatisch-historische Beschreibung des zum ehemaligen Primat und Ertz-Stifft nunmehr aber durch den westphälischen Friedens-Schluß secularisirten Herzogthum Magdeburg gehörigen Saal-Kreyses [...], Verlag des Waysenhauses, Halle, 1749.

Dudík, B.: Olmützer Sammel-Chronik vom Jahre 1432 bis 1656, Schriften der hist. stat. Sektion, Brno, 1858.

Dudík, B.: Geschichte des Benediktiner-Stiftes Raygern im Markgrafthume Mähren, II. Band, Vom Ende der Hussitenstürme bis in die Gegenwart 1449-1848, Druck und Verlag von Carl Herold's Sohn, Wien, 1868.

Egli, E. (Ed.): Heinrich Bullingers Diarium (Annales Vitae) der Jahre 1504-1574, in: Quellen zur Schweizer Reformationsgeschichte, vol. 2, Basler Buch und Antiquariatshandlung, Basel, 1-124, 1904.

Engel, A.: Annales Marchiae Brandenburgicae, Hartmann, Frankfurt/Oder, 1598.

Engel, W.: Die Rats-Chronik der Stadt Würzburg (XV. und XVI. Jahrhundert), Schöning in Komm., Würzburg, 1950.

Fischer, E. M., Seneviratne, S. I., Vidale, P. L., Lüthi, D., and Schär, C.: Soil moisture-atmosphere interactions during the 2003 European summer heat wave, J. Climate, 20, 5081-5099, https://doi.org/10.1175/JCLI4288.1, 2007.

Fischer, J. W.: Geschichte der königl. Hauptstadt und Gränzfestung Olmütz im Markgrafthume Mähren, I. Band, Auf Kosten des Verfassers, Olmütz, 1808.

Fouquet, G.: Bauen für die Stadt. Finanzen, Organisation und Arbeit in kommunalen Baubetrieben des Spätmittelalters. Eine vergleichende Studie vornehmlich zwischen den Städten Basel und Marburg, Böhlau, Köln, Weimar, Wien, 1999.

Freiherrn von Oefele, E. (Ed.): Leonhart Widmann's Chronik von Regensburg 1511-43: 1552-55, in: Die Chroniken der deutschen Städte, Bd. 15, Hiezel, Leipzig, 1878.

Friedrich, G.: Rukověť křesťanské chronologie (Handbook of Christian Chronology), Paseka, Praha, Litomyšl, 1997.

Fries, L.: Historie, Nahmen, Geschlecht, Wesen, Thaten, gantz Leben und Sterben der gewesenen Bischoffen zu Wirtzburg und Hertzogen zu Franken, in: Geschichtsschreiber von dem Bischoffthum Wirtzburg, edited by: Ludewig, J. P., Fritsch, Frankfurt, 1713.

Garnier, E: Historic drought from archives: Beyond the instrumental record, in: Drought. Science and Policy, edited by: Iglesias, A., Assimacopoulos, D., and Van Lanen, H. A. J., Wiley, Hoboken, USA, 45-67, 2019.

Ginschopff, J.: Chronica/Oder Eygendtliche Beschreibung vieler Denckhwürdigen Geschichten/die sich im Fürstenthumb Würt- temberg/sonderlichen vmb Stutgart her zugetragen [...], 2. Aufl., Durlach, 1631.

Glaser, R.: Klimageschichte Mitteleuropas. 1200 Jahre Wetter, Klima, Katastrophen, Primus Verlag, Darmstadt, 2008.

Gomolcke, D.: Historische Beschreibung derer grossen Theuerungen, Hunger und Kummerjahre, welche nicht allein die k.u.k. Stadt Breslau, sondern auch dan gantze Land Schlesien bis auf das 1737 Jahr betroffen, Welcher, Breslau, 1737.

Gradl, H. (Ed.): Die Chroniken der Stadt Eger, Deutsche Chroniken aus Böhmen, Band III, Im Auftrage des Vereins für Geschichte der Deutschen in Böhmen, Prag, 1884.

Gross, J. and Seraphin, F. W. (Eds.): Auszug aus der Chronik von Simon Massa, Marcus Fuchs u. a., Quellen zur Geschichte der Stadt Brassó, Vierter Band, Chroniken und Tagebücher, Erster Band, 1143-1867, Heinrich Zeidner, Brassó, 73-86, 1903a.

Gross, J. and Seraphin, F. W. (Eds.): Historien von Hieronymus Ostermayer (1520-1561), Quellen zur Geschichte der Stadt Brassó, Vierter Band, Chroniken und Tagebücher, Erster Band, 11431867, Heinrich Zeidner, Brassó, 496-522, 1903b.

Hansen, J. (Ed.): Die Chronik des Dietrich Westhoff, in: Die Chroniken der westfälischen und niederrheinischen Städte, 1: Dortmund, Neuß (Die Chroniken der deutschen Städte vom 14. bis ins 16. Jahrhundert, 20), S. Hirzel, Leipzig, 177-462, 1887.

Hauser, K. (Ed.): Die Chronik des Laurencius Bosshart von Winterthur, 1158-1532, in: Quellen zur schweizerischen Reformationsgeschichte, edited by: Egli, E., III., Basler Buch- und Antiquariatshandlung, Basel, 1905.

Henneberger, C.: Erclerung der Preussischen grössern Landtaffel oder Mappen, Osterberger/Schultze, Königsperg in Preussen, 1595.

Horváth, M.: Kisebb történelmi munkái (Smaller Works), Vol. 3, Ráth, Pest, 1868.

Hubatsch, W. and Arnold, U. (Eds.): Die Chronik des Johannes Freiberg, in: Hubatsch, W. (Ed.): Scriptores rerum Prussicarum, Bd. VI., Hirzel, Leipzig, 356-544, 1968.

Kętrzyński, W. (Ed): E codicibus Trzemesznensibus, in: Monumenta Poloniae Historica, Tom V, Akademia Umiejętności, Lwów, 967-988, 1888.

Kiss, A.: Droughts and low water levels in late Medieval Hungary II: 1361, 1439, 1443-4, 1455, 1473, 1480, 1482(?), 1502-3, 1506: Documentary versus tree-ring (OWDA) evidence, J. Environ. Geogr., 10, 43-56, https://doi.org/10.1515/jengeo-2017$0012,2017$.

Kiss, A.: Before and after the great heat and drought of 1540. Multiannual trends of grape and grain harvest dates in the Vienna Hospital Accounts, in: Genius Loci, edited by: Mérai, D., Drosztmér, Á., Lyublyanovics, K., Rasson, J., Papp Reed, Z., Vadas, A., and Zatykó, C., Laszlovszky 60, Archaeolingua, Budapest, 117-120, 2018.

Kiss, A.: The great (1506-)1507 drought and its consequences in Hungary in a (Central) European context, Reg. Environ. Change, 20, 50, https://doi.org/10.1007/s10113-020-01634-5, 2020.

Kiss, A. and Nikolić, Z.: Droughts, dry spells and low water levels in Medieval Hungary (and Croatia) I: The great droughts of 1362, 1474, 1479, 1494 and 1507, J. Environ. Geogr., 8, 11-22, https://doi.org/10.1515/jengeo-2015-0002, 2015.

Knauth, J. C.: Alt-Zellischer Chroniken Siebendter Theil, [...], Winckler, Dresden, Leipzig, 1722. 
Koch, H. (Ed.): Mag. Adrian Beiers Jenaische Annalen (15231599), Vopelius, Jena, 1928.

Koch, H. (Ed.): Die älteste Chronik der Stadt Jena (1532-1546), Vopelius, Jena, 1937.

Kolár, J. (Ed.): Marek Bydžovský z Florentina, Svět za tř́ českých králů. Výbor z kronikářských zápisů o letech 1526-1596 (Marek Bydžovský of Florentinum. The World in the Reign of Three Czech Kings. Selection from chronicle records for the years of 1526-1596), Svoboda, Praha, 1987.

Kronika Marcina Bielskiego (The Chronicle of Marcin Bielski), in: Zbior dzieiopisow Polskich we czterech tomach zawarty, Tom pierwszy, Drukarnia J[ego] K[rólewskiej] M[oś]ci y Rzeczypospolitey u XX. Societatis JESU, Warszawa, 1764.

Kundmann, J. C.: Die Heimsuchungen Gottes in Zorn und Gnade über das Herzogthum Schlesien in Müntzen, Siegert, Liegnitz, 1742.

Labbé, T., Pfister, C., Brönnimann, S., Rousseau, D., Franke, J., and Bois, B.: The longest homogeneous series of grape harvest dates, Beaune 1354-2018, and its significance for the understanding of past and present climate, Clim. Past, 15, 1485-1501, https://doi.org/10.5194/cp-15-1485-2019, 2019.

Lappenberg, I. M. (Ed.): Bernd Gyseke's Hamburger Chronik vom Jahre 810 bis 1542, in: Hamburgische Chroniken in niedersächsischer Sprache, Perthes, Besser und Mauke, Hamburg, 1-192, 1861.

Limanówka, D.: Rekonstrukcja warunków klimatycznych Krakowa w pierwszej połowie XVI wieku (Reconstruction of Climatic Patterns in Cracow in the First Half of the 16th Century), Materiały Badawcze, Seria: Meteorologia - 33, Instytut Meteorologii i Gospodarki Wodnej, Warszawa, 2001.

Luterbacher, J., Xoplaki, E., Dietrich, D., Jones, P. D., Davies, T. D., Portis, D., Gonzalez-Rouco, J. F., von Storch, H., Gyalistras, D., Casty, C., and Wanner, H.: Extending North Atlantic Oscillation reconstructions back to 1500 , Atmos. Sci. Lett., 2, 114-124, 2002a.

Luterbacher, J., Xoplaki, E., Dietrich, D., Rickli, R., Jacobeit, J., Beck, C., Gyalistras, D., Schmutz, C., and Wanner, H.: Reconstruction of Sea Level Pressure fields over the Eastern North Atlantic and Europe back to 1500, Clim. Dynam., 18, 545-561, https://doi.org/10.1007/s00382-001-0196-6, 2002b.

Luterbacher, J., Dietrich, D., Xoplaki, E., Grosjean, M., Wanner, H., Paeth, H., and Steiner, N.: European seasonal and annual temperature variability, trends and extremes since 1500, Science, 303, 1499-1503, https://doi.org/10.1126/science.1093877, 2004.

Luterbacher, J., Xoplaki, E., Rickli, R., Gyalistras, D., Schmutz, C., Wanner, H., Dietrich, D., Jacobeit, J., and Beck, C.: Luterbacher et al. 2002 Sea Level Pressure Reconstructions, N. Atlantic/Europe, National Centers for Environmental Information, NESDIS, NOAA, U.S. Department of Commerce, available at: https://www.ncdc.noaa.gov/paleo-search/study/6366, last access: 22 May 2020a.

Luterbacher, J., Dietrich, D., Xoplaki, E., Grosjean, M., Wanner, H., Paeth, H., and Steiner, N.: Xoplaki 2005, Luterbacher 2004 European Seasonal Temperature Reconstructions, National Centers for Environmental Information, NESDIS, NOAA, U.S. Department of Commerce, available at: https://www.ncdc.noaa.gov/ paleo-search/study/6288, last access: 22 May 2020 b.

Martín-Vide, J. and Barriendos Vallvé, M.: The use of rogation ceremony records in climatic reconstruction: A case study from Catalonia (Spain), Climatic Change, 30, 201-221, https://doi.org/10.1007/BF01091842, 1995.

Maurer R. (Ed.): Rocznika świętokrzyskiego dopełnienie drugie z kodeksu IX, 1492-1556 (Second Addition to Świętokrzyski Annals from Codex 9, 1492-1556), in: Monumenta Poloniae Historica, t. III, Akademia Umiejętności, Lwów, 88-118, 1878.

McKee, T. B., Doesken, N. J., and Kleist, J.: The relationship of drought frequency and duration to time steps, in: Preprints, 8th Conference on Applied Climatology, Anaheim, USA, 17-22 January 1993, 179-184, 1993.

Meier, N., Rutishauser, T., Pfister, C., Wanner, H., and Luterbacher, J.: Grape harvest dates as a proxy for Swiss April to August temperature reconstructions back to AD 1480, Geophys. Res. Lett., 34, L20705, https://doi.org/10.1029/2007GL031381, 2007.

Mikšovský, J., Brázdil, R., Trnka, M., and Pišoft, P.: Long-term variability of drought indices in the Czech Lands and effects of external forcings and large-scale climate variability modes, Clim. Past, 15, 827-847, https://doi.org/10.5194/cp-15827-2019, 2019.

Militzer, S.: CLIMDAT: Klima - Umwelt - Mensch (1500-1800), Leipzig, Germany, 1998.

Mitchell, T. D. and Jones, P. D.: An improved method of constructing a database of monthly climate observations and associated high-resolution grids, Int. J. Climatol., 25, 693-712, https://doi.org/10.1002/joc.1181, 2005.

Možný, M., Brázdil, R., Dobrovolný, P., and Trnka, M.: Cereal harvest dates in the Czech Republic between 1501 and 2008 as a proxy for March-June temperature reconstruction, Climatic Change, 110, 801-821, https://doi.org/10.1007/s10584011-0075-z, 2012.

Možný, M., Brázdil, R., Dobrovolný, P., Trnka, M., Potopová, V., Hlavinka, P., Bartošová, L., Zahradníček, P., and Žalud, Z.: Drought reconstruction based on grape harvest dates for the Czech Lands, 1499-2012, Clim. Res., 70, 119-132, https://doi.org/10.3354/cr01423, 2016.

Munzar, J.: Extreme droughts in Central Europe in the preinstrumental period, Morav. Geogr. Rep., 12, 13-23, 2004.

Mühlich, A. and Hahn, G.: Chronik der Stadt Schweinfurt, J. H. Morich, Schweinfurt, 1817.

Müller, J. T. E.: Pragmatische Geschichte der Theurung und anderer Beschwerden, welche unsere Vorfahren während der letzten sechs Jahrhunderte erfahren haben, hauptsächlich in Beziehung auf den jedesmaligen Einfluß der Witterung bei denselben, ein Versuch Leidenden und Menschenfreunden zu Beruhigung und Aufmunterung und Freunden der Naturkunde und der Oekonomie im weiteren Sinne zur Prüfung vorgelegt, Fiedler, Görlitz, 1806.

Nowosad, W. and Oliński, P.: The extreme year of 1540 in terms of climate variation from the perspective of historical sources derived from the Polish and Baltic territories, in: The Dance of Death in Late Medieval and Renaissance Europe. Environmental Stress, Mortality and Social Response, edited by: Kiss, A. and Pribyl, K., Routledge, London, UK and New York, USA, 146$155,2020$.

Olearius, J. C.: Historia Arnstadiensis: Historie der alt-berühmten Schwartzburgischen Residentz Arnstadt, Bielcke/Bachmann, Jena/Arnstadt, 1701.

Orth, R., Vogel, M., Luterbacher, J., Pfister, C., and Seneviratne, S.: Did European temperatures in 1540 exceed present-day records?, 
Environ. Res. Lett., 11, 114021, https://doi.org/10.1088/17489326/11/11/114021, 2016.

Palme, A.: Warnsdorf mit seinem historischen Denkwürdigkeiten von wessen Gründung an bis zum Jahre 1850, J. Hamann, B. Leipa, 1913.

Palmer, W. C.: Meteorological Drought, Office of Climatology Research Paper 45, U.S. Weather Bureau, Washington, USA, 1965.

Pauling, A., Luterbacher, J., Casty, C., and Wanner, H.: Five hundred years of gridded high-resolution precipitation reconstructions over Europe and the connection to large-scale circulation, Clim. Dynam., 26, 387-405, https://doi.org/10.1007/s00382005-0090-8, 2006.

Pauling, A., Luterbacher, J., Casty, C., and Wanner, H.: Pauling et al. 2006 European Gridded Seasonal Precipitation Reconstructions, National Centers for Environmental Information, NESDIS, NOAA, U.S. Department of Commerce, available at: https:// www.ncdc.noaa.gov/paleo-search/study/6342, last access: 8 January 2020.

Perjés, G.: The Fall of the Medieval Kingdom of Hungary: Mohacs 1526 - Buda 1541, Atlantic Research and Publications, Boulder, Colorado, USA, 1989.

Pfister, C.: Klimageschichte der Schweiz 1525-1860. Das Klima der Schweiz von 1525-1860 und seine Bedeutung in der Geschichte von Bevölkerung und Landwirtschaft, Band I-II, Verlag Paul Haupt, Bern, Switzerland, Stuttgart, Germany, 1988.

Pfister, C.: Wetternachhersage. 500 Jahre Klimavariationen und Naturkatastrophen (1496-1995), Paul Haupt, Bern, Switzerland, Stuttgart, Germany, Wien, Austria, 1999.

Pfister, C.: The "Black Swan" of 1540. Aspects of a European megadrought, in: Climatic Change and Cultural Transition in Europe, edited by: Leggewie, K. and Mauelshagen, F., Brill, Leiden, the Netherlands, 156-194, 2018.

Pfister, C. and Rohr, C. (Eds.): Euro-Climhist. Information System on the History of Weather and Climate, Bern Open Repository and Information System, https://doi.org/10.7892/boris.73059, 2015.

Pfister, C., Wetter, O., Brázdil, R., Dobrovolný, P., Glaser, R., Luterbacher, J., Seneviratne, S. I., Zorita, E., Alcoforado, M.-J., Barriendos, M., Bieber, U., Burmeister, K. H., Camenisch, C., Contino, A., Grünewald, U., Herget, J., Himmelsbach, I., Labbé, T., Limanówka, D., Litzenburger, L., Kiss, A., Kotyza, O., Nordli, Ø., Pribyl, K., Retsö, D., Riemann, D., Rohr, C., Siegfried, W., Spring, J.-L., Söderberg, J., Wagner, S., and Werner, J. P.: Treerings and people - different view on the 1540 Megadrought. Reply to Büntgen et al. 2015, Climatic Change, 131, 191-198, https://doi.org/10.1007/s10584-015-1429-8, 2015.

Piervitali, E. and Colacino, M.: Evidence of drought in Western Sicily during the period 1565-1915 from liturgical offices, Climatic Change, 49, 225-238, https://doi.org/10.1023/A:1010746612289, 2001.

Pribyl, K. and Cornes, R. C.: Drought in medieval and early modern England, part 1: the evidence, Weather, 75, 168-172, https://doi.org/10.1002/wea.3599, 2020.

Przybylak, R., Oliński, P., Koprowski, M., Filipiak, J., Pospieszyńska, A., Chorążyczewski, W., Puchałka, R., and Dąbrowski, H. P.: Droughts in the area of Poland in recent centuries in the light of multi-proxy data, Clim. Past, 16, 627-661, https://doi.org/10.5194/cp-16-627-2020, 2020.
Rechnungen aus 1526-1540, Quellen zur Geschichte der Stadt Kronstadt in Siebenbürgen, II., In Commission bei Albrecht \& Zillich, Kronstadt, 1889.

Réthly, A.: Időjárási események és elemi csapások Magyarországon 1700-ig (Meteorological Events and Natural Disasters in Hungary until 1700), Akadémiai Kiadó, Budapest, 1962.

Rezek, A. (Ed.): Poselkyně starých příběhův českých. Sepsal Jan Beckovský, kněz řádu Křížovníků s červenou hvězdou (Messenger of the Old Czech Stories. Written by Jan Beckovský, the priest of the order of the Knights with the Red Star), Díl druhý (1526-1715), Sv. první (L. 1526-1607), Dědictwí sw. Prokopa w Praze XVIII za rok 1878, Praha, 1879.

Riedel, A. F. (Ed.): Hafftitz, P., Microcronicon Marchium, in: Riedel's Codex diplomaticus Brandenburgensis, Sammlung der Urkunden, Chroniken und sonstigen Geschichtsquellen für die Mark Brandenburg und ihrer Regenten, [...], Des Vierten Hauptteils oder der Urkunden-Sammlung für die Orts- und spezielle Landesgeschichte erster Band, Morin, Berlin, 46-167, 1862.

Riemann, D., Glaser, R., Kahle, M., and Vogt, S.: The CRE tambora.org - new data and tools for collaborative research in climate and environmental history, Geosci. Data J., 2, 63-77, https://doi.org/10.1002/gdj3.30, 2015.

Roch, H.: Neue Laußnitz-, Böhm- und Schlesische Chronica, Klosse/Hempe, Leipzig/Torgau, 1687.

Roder, C. (Ed.): Heinrich Hugs Villinger Chronik von 1495 bis 1533, Litterarische Verein in Stuttgart, Tübingen, 1883.

Roggenkamp, T. and Herget, J: An extreme drought in the year $69 \mathrm{AD}$ on Lower Rhine. A quantitative reconstruction, Z. Geomorph., 59, 99-109, https://doi.org/10.1127/zfg_suppl/2015/S59205, 2015.

Rohr, C.: Extreme Naturereignisse im Ostalpen. Naturerfahrung im Spätmittelalter und am Beginn der Neuzeit, Böhlau Verlag, Köln, Weimar, Wien, 2007.

Rojecki, A., Girgus, R., and Strupczewski, W. (Eds.): Wyjątki ze źródeł historycznych o nadzwycajnych zjawiskach hydrologiczno-meteorologicznych na zemiach polskich w wiekach od X do XVI (A Selection from Historical Sources of Unusual Hydrological and Meteorological Phenomena on the Polish Territories from the 10th to 16th Century), Wydawnictwa Komunikacji i Łączności, Warszawa, 1965.

Schär, C. and Jendritzky, G.: Hot news from summer 2003, Nature, 432, 559-560, https://doi.org/10.1038/432559a, 2004.

Schlesinger, L.: Simon Hüttels Chronik der Stadt Trautenau (14841601), Dominikus, Prag, 1881.

Schönborn, T. (Ed.): Chronik Michael Steinbergs, in: Schweidnitzer Chronisten des XVI. Jahrhunderts, edited by: Schimmelpfennig, A. and Schönborn, T., Scriptores Rerum Prussicarum, Bd. XI, Josef Max and Comp., Breslau, 117-176, 1878.

Schuller, J. K.: XIV. Handschriftliche Vormerkungen aus Kalendern des sechzehnten und siebzehnten Jahrhunderts, in: Archiv des Vereins für siebenbürgische Landeskunde, Dritter Band, Verlag des Vereins, Hermannstadt, 348-386, 1848.

Shmakin, A. B., Chernavskaya, M. M., and Popova, V. V.: "Velikaya" zasucha 2010 g. na Vostochno-Evropeyskoy Ravnine: istoricheskiye analogi, cirkulyacionnyye mekhanismy (The Great drought of 2010 in the eastern European plain: Historical analogues, circulation mechanisms), Izvestiya RAN - Ser. Geogr., 6, 41-57, 2013. 
Simigianus, A.: Historia rervm Vngaricar. et Transsilvanic. ab anno M. CCCC. XC. vsque M. DC. VI. quatvor libris comprehensa nvnc primvm typis edita adnotationibvsque illvstrata, Liber I, Hochmeister, Cibinii, 1800.

Smetana, J. (Ed.): Nejstarší kronikářské záznamy litoměřických radních písařu (The earliest chronicle records of councillor scribes in Litoměřice), Litoměřicko, 14, 119-142, 1978.

Spangenberg, C.: Mansfeldische Chronica, A. Petri, Eisleben, 1572.

Steinbach, O.: Diplomatische Sammlung historischer Merkwürdigkeiten aus dem Archive des gräflichen Cisterzienserstifts Saar in Mähren, Erster Theil, In der Joh. Ferd. Edl. von Schönfeldischen Buchhandlung, Prag, Wien, Leipzig, 1783.

Struve, E. E. (Ed.): Mag. Johannes Hasse, Buergermeister zu Görlitz, Görlitzer Rathsannalen, in: Scriptores rerum Lusaticarum, Neue Folge, Vol. IV, Oberlausitzische Gesellschaft der Wissenschaften, Görlitz, 1870.

Szilágyi, S.: Gyulaffy Lestár történeti maradványai I. (The historical remnants of Lestár Gyulaffy I.), Magyar Történelmi Tár, Ser. 3, Vol. 16, M. Tud. Akadémia, Budapest, 109-145, 1893.

Tejedor, E., de Luis, M., Barriendos, M., Cuadrat, J. M., Luterbacher, J., and Saz, M. Á.: Rogation ceremonies: a key to understanding past drought variability in northeastern Spain since 1650, Clim. Past, 15, 1647-1664, https://doi.org/10.5194/cp-151647-2019, 2019.

Thúry, J.: Török történetírók (Turkish History Writers), Vol. 1, M. Tud. Akadémia, Budapest, 1893.

Tille, J.: Geschichte der Stadt Niemes und ihrer nächsten Umgebung, Druck und Verlag von A. Bienert, Niemes, 1905.

Trausch, J.: Chronicon Fuchsio-Lupino-Oltardinum sive Annales Hungarici et Transilvanici, I., 990-1630, Per Johannem Gött Typographum, Brassó, 1847.

Trauschenfels, E.: Deutsche Fundgruben zur Geschichte Siebenbürgens, Neue Folge, Album Oltardinum (1526-1629), Druck und Verlag von Johann Gött, Kronstadt, 1860.

Vereins-Ausschuß (Ed.): Nachrichten von den ehemals in den alten großen Kirchen zu Hermannstadt und Kronstadt befindlichen Wandchroniken, in: Archiv des Vereins für siebenbürgische Landeskunde, 4, 110-130, 1851.

Vicente-Serrano, S. M., Beguería, S., and López-Moreno, J. I.: A multi-scalar drought index sensitive to global warming: The Standardized Precipitation Evapotranspiration Index - SPEI, J. Climate, 23, 1696-1718, https://doi.org/10.1175/2009JCLI2909.1, 2010.

Vischer, W. and Stern, A. (Eds.): Die Chronik des Fridolin Ryff, 1514-1541, mit der Fortsetzung des Peter Ryff, 1543-1585, in: Basler Chroniken, Ersten Band, S. Hirzel, Leipzig, 1-189, 1872. von Falckenstein, J. H.: Thüringische Chronicka, oder vollständige Alt-, Mittel- und Neue Historie von Thüringen, Ritsche, Erfurt, 1738.
Walawender, A.: Kronika klęsk elementarnych w Polsce i w krajach sąsiednich w latach 1450-1586, Część I: Zjawiska meteorologiczne i pomory, Część II. Kronika klęsk elementarnych (A Chronicle of Natural Disasters in Poland and in Neighbouring Countries in the 1450-1586 Period, Part I. Meteorological Phenomena and Pestilence, Part II. A Chronicle of Natural Disasters), Badania z Dziejów Społecznych i Gospodarczych, Lwów, 1932.

Weber, S.: Árak a Szepességben (Prices in the Spiš), Történelmi Tár, M. Tud. Akadémia, Budapest, 1894.

Weck, A.: Der Chur-Fürstlichen Sächsischen weitberuffenen Residentz- und Haupt-Vestung Dresden Beschreib- und Vorstellung, Hoffmann \& Froberger, Nürnberg, 1679.

Werlich, E. (Ed.): Marx Welsers des Jüngeren Chronica der Weitberühmten Keyserlichen Freyen und des H. Reichs Statt Augspurg in Schwaben, C. E. Erben, Franckfurt am Mayn, 1595.

Wetter, O. and Pfister, C.: Spring-summer temperatures reconstructed for northern Switzerland and southwestern Germany from winter rye harvest dates, 1454-1970, Clim. Past, 7, 13071326, https://doi.org/10.5194/cp-7-1307-2011, 2011.

Wetter, O. and Pfister, C.: An underestimated record breaking event - why summer 1540 was likely warmer than 2003, Clim. Past, 9, 41-56, https://doi.org/10.5194/cp-9-41-2013, 2013.

Wetter, O., Pfister, C., Werner, J. P., Zorita, E., Wagner, S., Seneviratne, S. I., Herget, J., Grünewald, U., Luterbacher, J., Alcoforado, M.-J., Barriendos, M., Bieber, U., Brázdil, R., Burmeister, K. H., Camenisch, C., Contino, A., Dobrovolný, P., Glaser, R., Himmelsbach, I., Kiss, A., Kotyza, O., Labbé, T., Limanówka, D., Litzenburger, L., Nordli, Ø., Pribyl, K., Retsö, D., Riemann, D., Rohr, C., Siegfried, W., Söderberg, J., and Spring, J.-L.: The year-long unprecedented European heat and drought of 1540 - a worst case, Climatic Change, 125, 349-363, https://doi.org/10.1007/s10584-014-1184-2, 2014.

White, S., Pfister, C., and Mauelshagen, F. (Eds.): The Palgrave Handbook of Climate History, Palgrave Macmillan, London, UK, 2018.

Zemek, P. (Ed.): Bartoškova kronika (The Bartošek Chronicle), Muzeum J. A. Komenského v Uherském Brodě, Uherské Hradiště, 2004.

Zenz, E.: Die Taten der Trierer (Gesta Treverorum), Bd. 6: Von Boemund II. bis zum Tod Jakobs III. 1354-1581, Paulinus-Verl., Trier, Germany, 1962.

Zilynskyj, B. (Ed.): Letopis měšťna Nového Města pražského z let 1492 až 1539 (Annals of the burgher of the Prague New Town from 1492-1539), Pražský Sbor. Hist., 17, 52-89, 1984. 